\title{
A dorozsmai márvány (Tiszai-fóegység) kốzettani újravizsgálata: deformáció és fluidum hatása a mikroszerkezet fejlődésére
}

\author{
PAPP Nikoletta*, VARGA Andrea, MÉSZÁros Előd, RAUCSIK Béla \\ SZTE TTIK Ásványtani, Geokémiai és Kőzettani Tanszék „Vulcano” Kőzettani és Geokémiai Kutatócsoport, 6722 Szeged, Egyetem utca 2. \\ *levelező szerző, e-mail: pappnicki@gmail.com
}

\section{Petrographic analyses of marbles: characteristic features of deformation and fluid-related effects in the Dorozsma marble (Tisza Mega Unit, South Hungary)}

Abstract

Detailed petrographic studies on marbles are rare in the Hungarian geological literature. Determination of the mineral phases and their grain size, examination of the grain boundaries as well as deformation microstructures, however, can provide a comprehensive information about the metamorphic evolution and the deformation history of a marble unit.

The metamorphic basement block near the village of Dorozsma contains a few-meter-thick marble zone within the Békés-Codru Zone. A petrographic study of archive thin sections representing this marble zone was carried out from the boreholes Dorozsma-4, Dorozsma-7 and Dorozsma-54

The fine-grained marble samples show heteroblastic texture with a composition of carbonate + quartz + muscovite + Mg-chlorite \pm talc. The carbonate crystal boundaries are dominantly sutured, embayed and rarely curved. All the morphological types of deformation twins appear in the samples, but dominantly twin types II and IV are present. The characteristic features of the samples are small dissolution cavities filled with fine crystalline carbonate, blocky quartz and, in some cases, with saddle dolomite. In the samples from the borehole Dorozsma-4 small inclusion free carbonate grains substitute the deformation twins of the large carbonate crystals. In addition, small carbonate neoblasts and $\mathrm{Mg}$ chlorite flakes can be found among the large carbonate crystals. Characteristic microstructures of the samples from the well Dorozsma-7 are large sigmoid carbonate clasts in a very fine-grained matrix. The deformation twins of the carbonate clasts can be easily identified and show the signs of recrystallization. These samples beside the carbonate clasts also contain irregularly shaped polycrystalline quartz grains with dissolved edges, undulose extinction and signs of incipient dynamic recrystallization.

The microstructures presented above suggest a polyphase deformation. The $\mathrm{D}_{1}$ deformation event took place above $250{ }^{\circ} \mathrm{C}$ based on the relict microstructures. The subsequent $\mathrm{D}_{2}$ ductile deformation event was a low-temperature dynamic recrystallization with a simple shear component, which could be the result of a hydrolitic weakening effect of hydrothermal fluids during deformation of the Dorozsma marble.

Keywords: Dorozsma, marble, petrography, ductile deformation, metasomatism

Összefoglalás

A márványok petrográfiai vizsgálata napjainkig alárendelt szerepet kapott a hazai földtani szakirodalomban. A márványt felépítő ásványfázisok, valamint azok szemcsemérete és a szemcsehatár jellegének meghatározása (kőzetszövet), illetve a deformációs bélyegek feltárása és értelmezése révén azonban átfogó képet kaphatunk a kőzet metamorf fejlődéséról és deformációtörténetéról, ami független bizonyítékokkal szolgálhat a befoglaló metamorf kőzettest korrelációjához.

A Békés-Codrui-egységen belül elhelyezkedő, Dorozsma környéki kristályos aljzatban egy maximum néhányszor tíz méter vastagságú, markáns töréses deformációt szenvedett márványzóna található. Tanulmányunkban az e zónát mintázó Dorozsma-4, -7 és -54 fúrások által feltárt márványból készült archív vékonycsiszolatok petrográfiai vizsgálatát végeztük el.

A mikroszkópos vizsgálatok alapján a dorozsmai márvány döntően karbonát + kvarc + Mg-klorit \pm talk összetételú, finomszemcsés, heteroblasztos szövetű márványból épül fel. A szemcsehatárok jellemzően szutúráltak, illetve beöblösödők, a deformációs ikerlemezek közül dominánsan a II. és a IV. típus van jelen. A mintákban általánosan jellemzők a kisméretû, kvarccal és karbonáttal kitöltött oldódásos üregek, amelyeket mikrokristályos karbonátból álló szegély övez. Erôsen átalakult, mikrokristályos kőzetváltozat szintén megfigyelhetô, valamint nagyméretú, szigmoid-alakú karbonátklasztok és rezorbeált, polikristályos, alszemcsés szerkezetú kvarcklasztok is megjelennek a mikrokristályos alapanyag- 
ban. Helyenként a nagyméretû karbonátszemcsék deformációs ikerlemezeit apró, kisméretú, zárványmentes karbonátszemcsék helyettesítik, amelyek a nagyméretû szemcsék között is megtalálhatók Mg-klorittal együtt.

Az archív vékonycsiszolatok petrográfiai vizsgálata alapján kijelenthetô, hogy a vizsgált márványt többfázisú deformáció érte. $\mathrm{A} \mathrm{D}_{1}$ esemény a szöveti bélyegek alapján nagyobb, $250{ }^{\circ} \mathrm{C}$-ot meghaladó hőmérsékleten mehetett végbe, amelyet később felülbélyegzett egy kis hőmérsékletú deformációs esemény $\left(\mathrm{D}_{2}\right)$, amelyhez fluidumhatás társult. E fluidum gyengítő hatása okozhatta a vékonycsiszolati léptékben felismerhető képlékeny alakváltozást, valamint a kis hőmérsékletú dinamikus rekrisztallizációra utaló szöveti bélyegeket.

Tárgyszavak: Dorozsma, márvány, petrográfia, képlékeny deformáció, metaszomatózis

\section{Bevezetés}

Márványnak nevezzük azokat a dominánsan kalcitból és/vagy dolomitból felépüló metamorf kőzeteket, amelyek protolitja mészkő vagy dolomit (WINTER 2001, BEST 2003). Általánosan jellemzó, hogy a márványok metamorf kôzettani szempontból kevesebb figyelmet kapnak, mint a bonyolultabb kémiai rendszert képviselő metabázitok vagy metapelitek. Ennek köszönhetô, hogy a márványokkal foglalkozó nemzetközi szakirodalomban elérhető munkák jelentős része archeometriai vonatkozású (PolikReTI \& MANIATIS 2002, ZöLDFÖLDI 2003, IORDANIDIS et al. 2008, MELFOS et al. 2010, ZÖLDFÖLDI 2011, AL-BASHAIREH \& AL-HOUSAN 2015, ANTONELLI et al. 2015, BRILLI et al. 2015, RicCA et al. 2015). Fontos azonban megemlíteni, hogy a kristályos karbonátkőzetekkel kapcsolatban — azok ásványtani egyszerúsége és relatíve könnyú deformálhatósága következtében - számos kózetdeformációs tanulmány született (pl. Koroknai 2004, Németh \& Mádai 2004, RybaCKi et al. 2013).

Hazánk területén számos márványból felépülố képződmény található, melyek közül néhányat az 1 . ábra mutat be. Az Észak-Magyarországon feltárt kôzeteket a rétegtan többek között a Rakacai Márvány, a Rakacaszendi Márvány, illetve a Bükhegyi Márvány Formációba sorolta (LESS et al. 2006). A fenti litosztratigráfiai egységek alapvetố kőzettani leírásán túl azokban paleontológiai vizsgálatokat és szerkezetföldtani kutatásokat végeztek (pl. FüLÖP 1994, KoROKNAI 2004, SudAR \& KovÁCs 2006). A Tiszai-főegység kristályos aljzatában szintén jelen vannak néhányszor tíz méteres vastagságú márványtestek (pl. a Dunántúlon: Ófalui Komplexum, illetve Baksa-2 fúrás; az Alföldön: Dorozsma-4, -7, -54, Algyő-85 fúrás). A Dél-Alföld aljzatában található márványokról azonban meglehetôsen szegények az ismereteink (1. és 2. ábra). Az általános szöveti leíráson és az indexásványok vizsgálatán túl részletes petrográfiai, fejlődéstörténeti elemzésükre eddig nem került sor (FÜLÖP 1994, SZEDERKÉNYI 1996, LeLKES-FELVÁRI et al. 2005, FinTOR et al. 2008, M. То́тн 2008).

Munkánkban az NKFIA (OTKA) K 108375 kutatáshoz — projektcím: Az Algyői-aljzatmagaslat és a környező mélymedencék (Dorozsmai-medence, Makói-árok) integrált diagenezis-történeti és fluidumevolúciós rekonstrukciója — kapcsolódva a dorozsmai márványzóna petrográfiai vizsgálatát végeztük el archív vékonycsiszolati gyứjtemény felhasználásával. A fenti projekt elsődleges célja a preneogén aljzatkőzetek, valamint azok repedéskitöltő fázi- sainak kutatása. A márványzóna részletes reambulációjának első lépéseként tanulmányunkban a márványok petrográfiai leírásához elengedhetetlen szempontokat foglaljuk össze, majd a Dorozsma-4, -7 és -54 fúrások által feltárt márvány vizsgálati eredményeit mutatjuk be, végül felvázoljuk a továbblépés (pl. korreláció) lehetôségeit.

\section{Márványpetrográfia — módszertani lehetôségek}

Az archeometriai szempontból jelentôs forrásterületvizsgálatok kapcsán a márványok vizsgálata során több analitikai módszer együttes alkalmazása jellemző. A standard vékonycsiszolatok polarizációs mikroszkópos vizsgálatával az adott minta petrográfiai jellemzőiról kapunk képet. A petrográfiai vizsgálatok során a kőzet színe és összetétele, tehát az esetleges metamorf indexásványok, valamint az akcesszórikus ásványfázisok meghatározásán túl figyelembe kell venni a kőzetalkotó ásványfázisok szemcseméretét, a szemcsék érintkezésének módját, a kôzet szövetét, mely paraméterek a kőzet metamorf fejlődéstörténetérôl hordoznak információt. További fontos jellemző lehet a deformációs ikerlemezek megjelenése, illetve azok morfológiai típusai és a dinamikus, valamint a statikus átkristályosodás eredményeként kialakult szöveti bélyegek (MeLFos et al. 2010, ABu-JABER et al. 2012, ANTONELLI et al. 2015). Mindezen szempontok figyelembe vételével átfogó képet kaphatunk a kőzet metamorf fejlődéséról és deformációtörténetéról egyaránt. A következókben szakirodalmi adatok alapján tekintjük át ezeket a legfontosabb petrográfiai szempontokat.

\section{Szín és összetétel}

A tiszta márvány, illetve dolomárvány jellemzően fehér színú, amely az akcesszórikus ásványfázisok függvényében megváltozhat, grafit jelenlétében a márvány gyakran szürkés elszíneződésú, míg vas-oxid jelenléte rózsaszínúre színezheti a kőzetet (MelFos et al. 2010). Járulékos ásványként előfordulhat klorit, illetve szericit a márványban, amelyek a kőzet szürke, zöldeszürke színét okozhatják (KOROKNAI 2004). Összetétel szempontjából mind a kôzetalkotó ásványok (kalcit, dolomit), illetve a metamorf indexásványok meghatározása, mind az akcesszórikus ásványfázisok fontos szerepet kapnak (I. tábla, $A-D)$, hiszen a különböző genetikájú márványok közötti elsődleges különbség az őket 

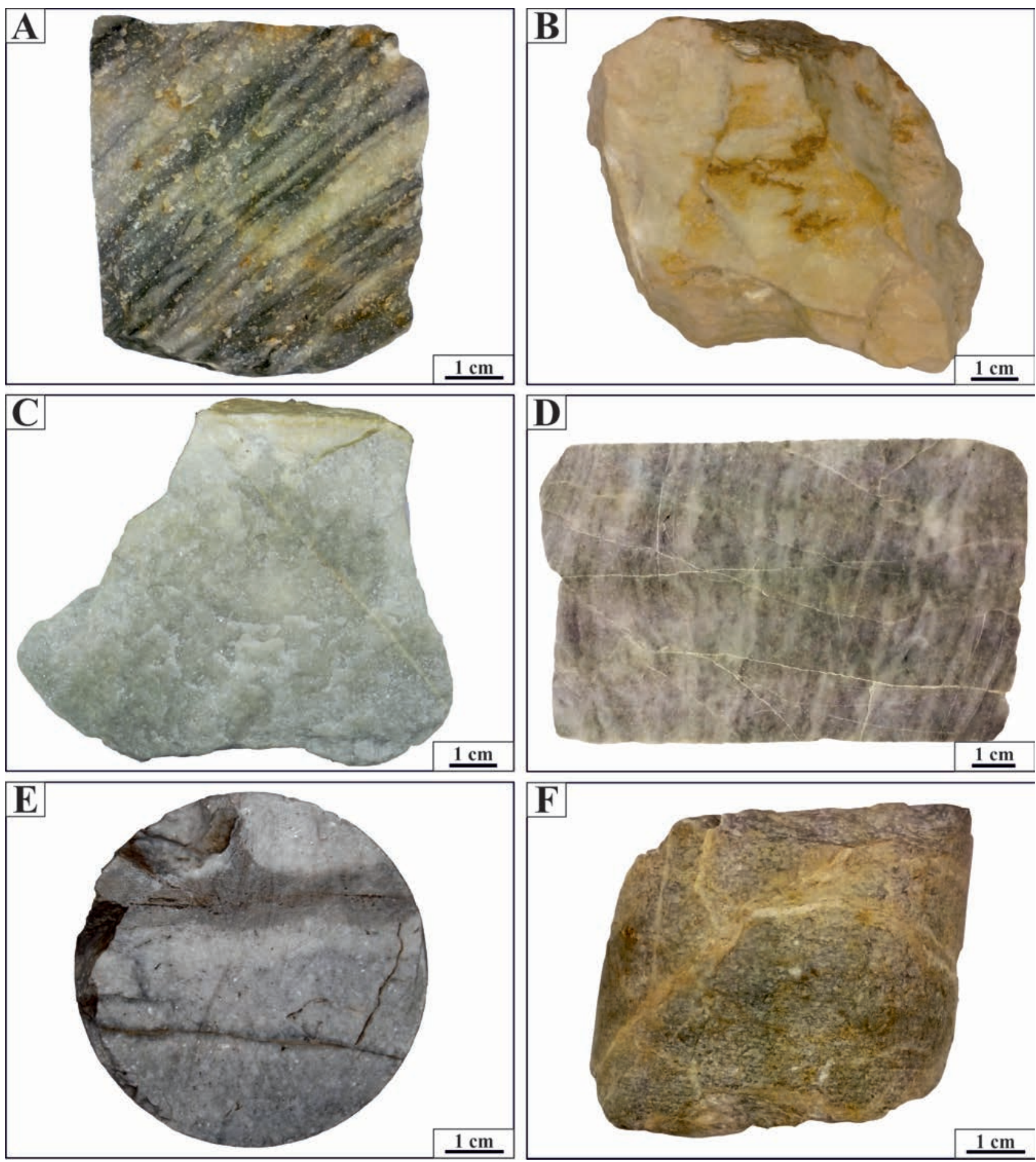

1. ábra. Jellegzetes magyarországi márványkifejlődések makroszkópos megjelenése. (A) Rakacai Márvány Formáció (Rakacaszend), karbon; (B) A devon Bükhegyi Márvány (Bük-hegy, Szendrőlád); (C) Középső-devon Polgárdi Mészkő Formáció tipikus kristályos mészköve (Kőszár-hegy); (D) A Baksa-2 fúrás által feltárt Baksai Komplexumban található márvány (101,1 m); (E) A dorozsmai márvány a Dorozsma-54 (3033-3038 m) és a (F) Dorozsma-4 (3053-3055 m) fúrásból.

Figure 1. Macroscopic features of some marble formations from Hungary. (A) Rakaca Marble, Carboniferous (Rakacaszend); (B) Bükhegy Marble, Devonian (Bük Hill, Szendrölád); (C) Polgárdi Limestone, Middle Devonian (Köszár Hill); (D) Marble of the Baksa Complex from the borehole Baksa-2 (101.1 m); (E) Dorozsma marble from the borehole Dorozsma-54 (3033-3038 m); (F) Dorozsma marble from the borehole Dorozsma-4 (3053-3055 m)

felépítő ásványfázisokban mutatkozik meg (CAPEDRI et al. 2004, BoRGHI et al. 2009, ANTONELLI et al. 2015).

A márványokban előforduló metamorf indexásványok jelenlétét a nyomáson és a hőmérsékleten túl nagymérték- ben befolyásolja a $\mathrm{CO}_{2}$ koncentrációja $\left(\mathrm{xCO}_{2}\right)$. Az egyes gyakori indexásványok (pl. talk, tremolit, diopszid, forsterit) általában széles p- $\mathrm{T}-\mathrm{xCO}_{2}$ tartományban stabilak (3. ábra, BUCHER \& GRAPES 2011). 


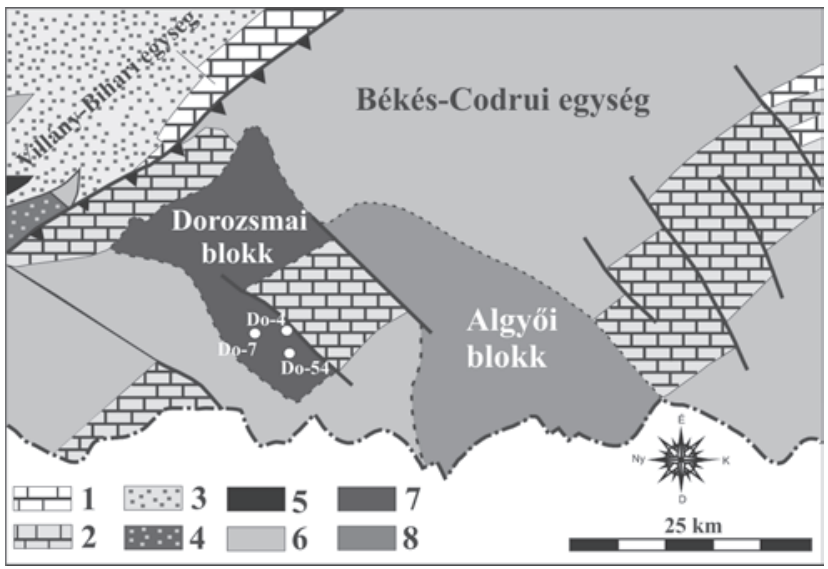

2. ábra. A Dél-Alföld aljzatának vázlatos földtani térképe (LELKES-FELVÁRI et al. 2005 alapján módosítva)

(1) Felső-jura-alsó-kréta békési típusú képződmények; (2) Triász képződmények; (3) Turon-senon tengeri képződmények; (4) Villányi típusú jura képződmények; (5) Permi riolitos vulkanitok; (6) Kristályos aljzat általában; (7) Gneisz, márvány, amfibolit; (8) Csillámpala, gneisz

Figure 2. Simplified geological map of the studied area (modified after LELKESFELVÁRI et al. 2005)

(1) Upper Jurassic to Lower Cretaceous Békés-type successions (2) Triassic successions (3) Turonian-Senonian marine successions (4) Villány-type Jurassic successions (5) Permian rhyolitic volcanic rocks (6) Crystalline basement rocks (7) Gneiss, marble and amphibolite (8) Mica schist and gneiss

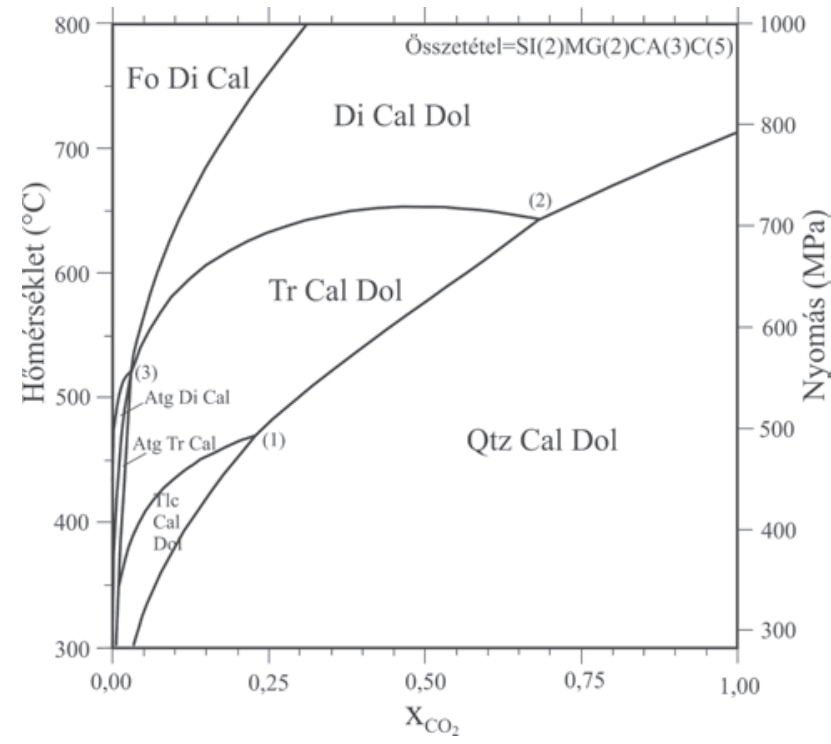

3. ábra. A márványokban megjelenő szilikátásványok stabilitási tartománya 300-800 ${ }^{\circ} \mathrm{C}$ és $300-1000 \mathrm{MPa}$ között, változó xCO , tartalom mellett (BuCHER \& GRAPES 2011, módosítva). Rövidítések: Atg: antigorit; Cal: kalcit; Di: diopszid; Dol: dolomit; Fo: forsterit; Tlc: talk; Tr: tremolit; Qtz: kvarc

Figure 3. The T-p-XCO diagram showing the phase equilibria of siliceous dolomites between $300-800^{\circ} \mathrm{C}$ and $300-1000 \mathrm{MPa}$ pressure and a changing $\mathrm{xCO}_{2}$ content of the pore fluid (modified after BUCHER \& GRAPES 2011). Abbreviations: Atg: antigorite; Cal: calcite; Di: diopside; Dol: dolomite; Fo: forsterite; Tlc: talc; Tr: tremolite; Qtz: quartz

\section{Szemcseméret}

Petrográfiai vizsgálatok során az összetétel megállapítását követően a domináns szemcseméret meghatározása, továbbá a vizsgált mintában a maximális szemcseméret (maximum grain size - MGS) meghatározása szükséges. A maximális szemcseméret nagysága jelentôs diagnosztikai paraméter, mivel szorosan kapcsolódik a kőzet metamorf fejlődéstörténete során elért maximális hőmérséklethez (BORGHI et al. 2009, MoEns et al. 1988). A domináns szemcseméret alapján négy kategória különböztethetô meg: durva-, közép-, finom-, illetve nagyon finomszemcsés márvány elkülönítése javasolt. Durvaszemcsés márványról >3 mm szemcseméret esetén beszélünk, középszemcsésről 2-3 mm között, míg finomszemcsésről 1-2 mm átlagos szemcseméret között van szó. Nagyon finomszemcsés márványnál a domináns szemcseméret <1 mm (BorGHI et al. 2009, ANTONELLI et al. 2015).

\section{Szemcseméret eloszlás}

A szemcseméret mellett a márványok szövete is diagnosztikai jelentőséggel bír, hiszen a kőzetet ért metamorfózis fokát tükrözi (GoRGONI et al. 1998, LAZZARINI et al. 1980). A márványok esetében a szemcseméret eloszlása szerint alapvetően két fő szöveti kategóriát különböztetnek meg a metamorf kőzettanban általánosan használt granoblasztos szövet pontosításaként: a homeoblasztos és a heteroblasztos szövetet. Homeoblasztos szövetnél a kózetet alapvetően azonos méretú (ekvigranuláris) szemcsék építik fel, ezzel ellentétben heteroblasztos szövetról akkor beszélhetünk, ha a kôzetet különbözó mérettartományba eső szemcsék alkotják (CAPEDRI et al. 2004, ABU-JABER et al. 2012). Abban az esetben, ha a márvány megfelelő (>2 V/V\%) mennyiségben tartalmaz filloszilikátokat, az átkristályosodás során a karbonátszemcsék növekedése és a szemcsék alakjának változása egyaránt gátolt, ennek eredményeként jellemzően kisebb szemcseméret és a filloszilikátok által meghatározott, irányított szövet jön létre a kôzetben (EBERT et al. 2008).

\section{A szemcsehatár jellege}

Metamorf átkristályosodás során a kőzetet felépítő szemcsék a szemcsehatár felületi energiájának csökkentésére törekednek. A kőzetet alkotó szemcsék érintkezésének jellegét, valamint a szemcsék egymással bezárt szögét a szemcsék felületi energiája és a felületi tenzió közötti arány határozza meg (4. ábra). Ha azonos összetételú ásványfázisok között a szemcsék érintkezése egyenes vonalú, illetve $120^{\circ}$-os szemcseérintkezési szög jellemző (II. tábla, A), akkor az a felületi energia és a felületi tenzió közötti egyensúlyra utal. Amennyiben a kőzet nem érte el ezt a szöveti egyensúlyt, az egyenestôl eltérô, hajlott, beöblösödő vagy szutúrált szemcsehatár lesz jellemző (II. tábla, B) (KARACA et al. 2015, GorGONi et al. 1998).

\section{Deformációs ikresedés}

A karbonátásványokban a deformációs ikresedés már kis hômérsékleten megjelenô deformációs mechanizmus. Az ikerlemezek morfológiája, szélessége, továbbá súrúsége és az aktiválódott ikerrendszerek száma a deformáció hőmérsékletével és a redukált feszültséggel (differential stress) van összefüggésben. Ennek következtében az ikre- 


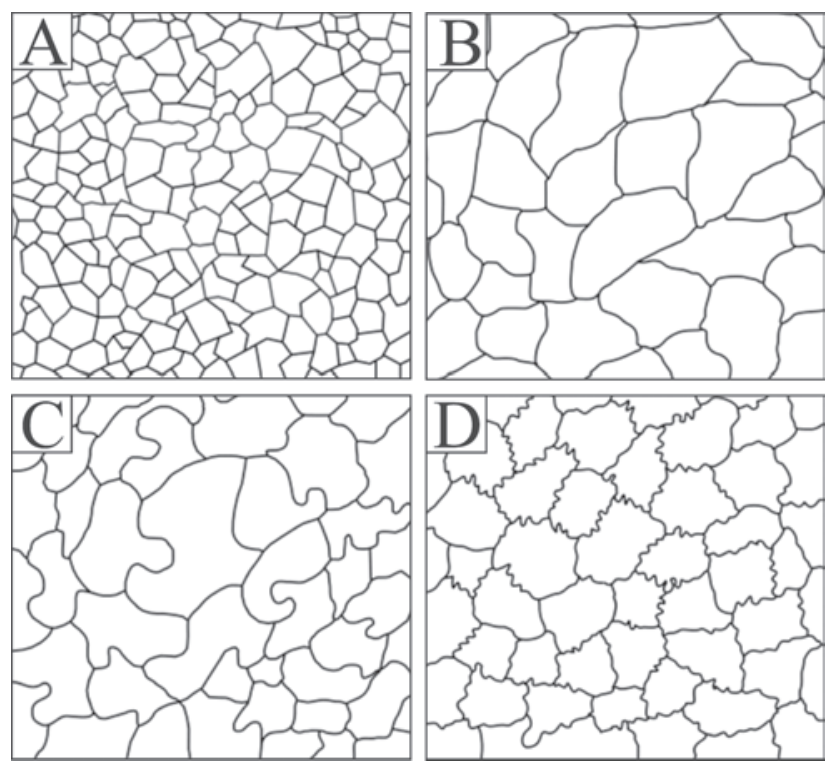

4. ábra. Jellegzetes szemcsehatárok márványban. (A) Egyenes szemcsehatárok egyensúlyi szövetben; (B) Márvány ívelt szemcsehatárokkal; (C) Beöblösödő, valamint (D) szutúrált szemcsehatárok márványban

Figure 4. Schematic illustration of grain boundary types in marbles. (A) straight grain boundaries; $(B)$ curved grain boundaries; $(C)$ embayed boundaries; $(D)$ sutured grain boundaries

sedést gyakran alkalmazzák geotermométerként karbonáttartalmú kőzetekben (JANSSEN et al. 2007, BURKHARD 1993, FERILL et al. 2004). Dolomitban a $\{012\}$ a gyakori ikresedési sík (f-sík), míg a nagyobb szimmetriával rendelkező kalcitban elsődlegesen az e-síkon \{018\} történik a deformációs ikerlemezek kialakulása (BARBER \& WENK 1979).

A vékonycsiszolatok petrográfiai vizsgálata alapján általánosan elfogadott, hogy a kis hőmérsékleten $(<170$ $200{ }^{\circ} \mathrm{C}$ ) képződött ikerlemezek nagy nagyítás mellett is csupán vékony fekete vonalakként jelennek meg a kristályban. A hőmérséklet növekedésével fokozatosan vastagabb, táblás megjelenésú ikerlemezek fejlődnek ki, majd lencseszerú vagy a szemcsehatár felé elvékonyodó és hajlott deformációs ikrek jönnek létre. Nagy hőmérsékleten, a dinamikus átkristályosodás aktiválódásával és egyre növekvő dominanciájával az ikerlemezek határa szabálytalanná válik. A rekrisztallizáció előrehaladtával apró „foltok sorozata” jelöli ki az eredeti ikerlemez helyét a kristályban. A hőmérséklet növekedésével változó morfológia alapján a karbonátokban a deformációs ikerlemezek négy típusát különböztetjük meg (5. ábra; I. tábla, E-H; BURKHARD 1993, FERILL et al. 2004).

A különböző összetételú karbonátokban (például kalcitban és dolomitban) bár hasonló morfológiájú ikrek jellemzőek, az egyes ikertípusokat létrehozó deformáció hőmérséklete meglehetősen eltérő lehet. Kis hőmérsékleten a dolomit jóval ridegebb a kalcitnál, ezért $300{ }^{\circ} \mathrm{C}$-nál kisebb hőmérsékleten abban deformációs ikresedés nem jellemző (PASSCHIER \& TROUw 2005). JANSSEN et al. (2007) azonban vitatja a hőmérséklet és az ikerlemezek morfológiája közötti közvetlen összefüggést, mivel korábbi kutatások során több mintában a kalcit deformációs ikerlemezei alapján becsült hőmérséklet nem egyezett meg más, független módszerrel — például vitrinit-reflexió, conodonta színindex — becsült hőmérséklettel.
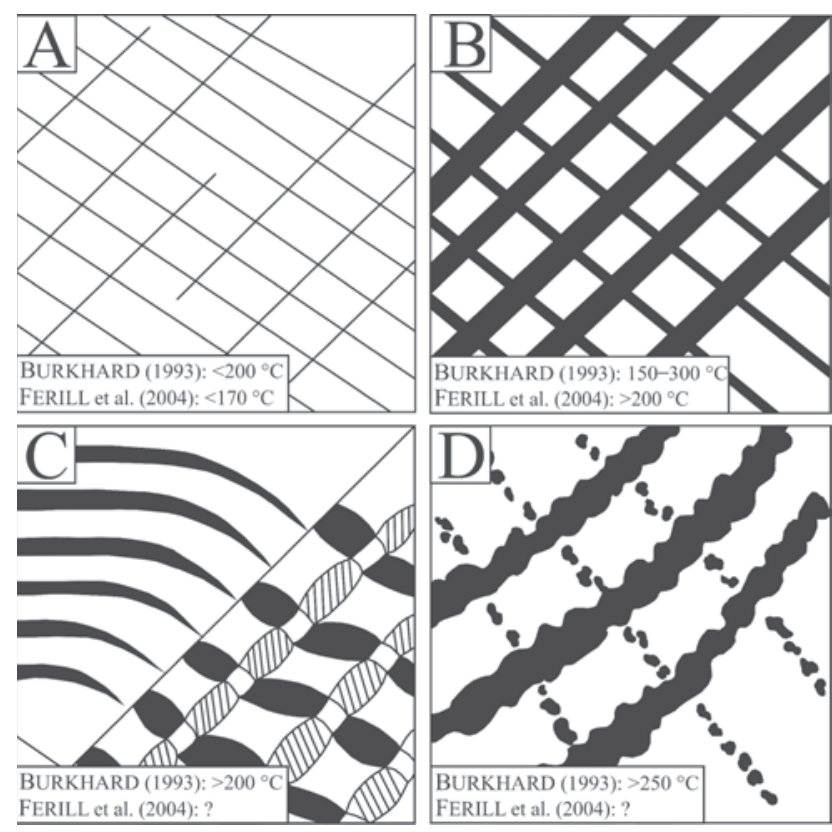

5. ábra. A karbonátokban megjelenő deformációs ikerlemezek morfológiai típusai (Burkhard 1993 és FERILl et al. 2004 alapján módosítva). (A) I. típusú ikerlemezek: $1 \mu \mathrm{m}$-nél vékonyabb vonalak; (B) II. típusú ikerlemezek: vastag, táblás megjelenésủek; (C) III. típusú ikerlemezek: gyakran lencseszerűek, vagy a szemcsehatár felé fokozatosan elhajlanak és elvékonyodnak; (D) IV. típus: az ikerlemezek határa szutúrált, azokat gyakran csupán apró foltok sorozata rajzolja ki

Figure 5. The schematic illustration of different types of deformation twins in calcite (modified after BURKHARD 1993 and FERILL et al.2004). (A) Type I thin twins, their thickness is less than $1 \mu$ m; (B) Type II thick, tabular twins; (C) Type III thick lensoid and curved twins; (D) Type IV thick patchy twins or the trails of tiny grains

Az ikerlemezek szélessége és súrúsége együttesen adja meg a szemcse által elszenvedett alakváltozás mértékét. Egyszerú nyírás során az alakváltozás sebességének növekedésével az ikerlemezek sûrűsége jellemzően növekszik, vele párhuzamosan pedig az ikerlemezek vastagsága csökken, az így kialakuló ikerlamellák nem sorolhatók be egyértelmúen a BURKHARD (1993) által meghatározott típusokba. Ezzel ellentétben a deformáció sebességének csökkenésével növekvő vastagságú és kisebb sûrûségú ikerlemezek alakulnak ki a kalcitban (RYBACKI et al. 2013).

\section{A dorozsmai márvány petrográfiai vizsgálata - földtani háttér}

A Tiszai-fóegység aljzatát tektonikailag különálló prealpi és alpi részegységek rendszere építi fel (HAAs \& BUDAI 2010). A Tiszai-főegységen belül három prealpi terrénumot, a Szlavóniai-Drávai-, a Kunsági-, valamint a Békési-terrénumot különböztették meg, amelyek további alegységekre tagolhatók (KovÁCS et al. 2000, SZEDERKÉNYI 2001, CSÁSZÁr 2005). Az alpi orogenezis során zajlott takaróképződés 
alakította ki a terület jelenlegi övezetes elrendeződését (Mecseki-, Villányi-, Békés-Codrui-, illetve Kisbihari-zóna). TARI et al. (1992) szeizmikus vizsgálatok alapján a terület nagymértékú extenzióját állapították meg a középső-miocén során, és ezzel magyarázták a lokálisan megjelenő közepes-nagyfokú metamorfózist szenvedett képződmények jelenlegi helyzetét.

Dorozsma környékén az aljzatot SzEDERKÉNYI (1984) a Tiszai Formációba sorolta, CsÁszÁR (2005) pedig a Csongrádi (Tiszai) Komplexum részeként említi. A szakirodalomban először LELKES-FELVÁRI et al. (2005) kezelik önálló komplexumként a képződményt a Békési-terrénumon belül (,Dorozsmai Komplexum”), és a Dorozsma környéki metamorfitokat az algyői aljzatmagaslaton feltárt kristályos képződményekkel analógnak tekintik (2. ábra). A dorozsmai aljzat átfogó, részletes vizsgálata M. Tóтн (2008) munkájához köthető, aki azt metamorf magkomplexumként értelmezte.

A dorozsmai metamorf blokk szerkezetileg három fő litológiai egységre osztható fel (M. TóTH 2008). A felső egységet dominánsan csillámpala és gneisz építi fel, alárendelten metapegmatit betelepülésekkel. Ezzel szemben az alsó egység amfibolos biotitgneiszból és amfibolitból áll. Nemcsak a kőzettani összetételben, hanem a metamorfózis maximális hőmérsékletében is jelentős különbség van a két egység között. Míg a felső egységre M. TóтH (2008) 560 ${ }^{\circ} \mathrm{C}$-ot becsült, addig az alsó szerkezeti egység maximális metamorf hômérsékletére $\sim 520^{\circ} \mathrm{C}$ feltételezhetô. Az eddigi kutatások alapján a két egység között egy maximum néhányszor tíz méter vastag márványzóna található. E zóna tanulmányozásakor LELKES-FELVÁRI et al. (2005) különböző típusú márványokat dokumentáltak, tisztán kalcitból álló márványt, dolomárványt, illetve talkot és Mg-kloritot tartalmazó márványtípust különítettek el. Eredményeik alapján a kalcitból álló márványt finom-középszemcsés, granoblasztos szövet jellemzi, a szemcséken deformációs ikresedést és alapvetően szemcsehatárvándorlásos dinamikus rekrisztallizáció jeleit azonosították. A finomszemcsés dolomárványban deformációs ikresedést nem figyeltek meg, azonban repedések, szemcsehatárok mentén kisméretú, átkristályosodott szemcséket azonosítottak. Ezeken túlmenően milonitos deformációt, valamint kataklázosodott kőzetváltozatokat szintén kimutattak.

M. Tóтн (2008) véleménye szerint a márványzóna erős töréses deformációt szenvedett, breccsásodott, amit a korakréta tektonikus események során a gneisz és a dolomárvány között fellépô reológiai különbség okozhatott. Megállapításai szerint a márványzóna nem képezte részét az eredeti kőzetoszlopnak, a kiemelkedést követően, a későbbi kompressziós mozgások révén kerülhetett jelenlegi helyzetébe. A kőzetet intenzíven nyírt, apró szemcsék alkotják, a nagyobb méretú szemcséken deformációs ikresedés figyelhető meg, míg poligonális szövet meglehetôsen ritkán fordul elő. A képződmény maximális metamorf hőmérséklete M. Тóтн (2008) szerint a dolomit mellett kis mennyiségben jelenlevő szilikátfázisok (kvarc + Mg-klorit + talk), továbbá a dolomitszemcsék rekrisztallizációjának hiánya alapján feltehetôleg nem érte el a $450{ }^{\circ} \mathrm{C}$-ot.

\section{Mintagyújtés, módszerek}

Munkánk során a Dorozsma-4, a Dorozsma-7 és a Dorozsma-54 (5., 6. és 14. magfúrások, 2973 m, 2981 m, illetve 3035-3040 m közötti szakaszok) fúrások által harántolt márványból készült, összesen 18 darab vékonycsiszolat petrográfiai vizsgálatát végeztük el, amelyeket a MOL Nyrt. bocsátott rendelkezésünkre. A vékonycsiszolatok lineációhoz, illetve foliációhoz viszonyított orientációjáról nincs információnk, így a levonható szerkezeti következtetések igen korlátozottak. A vékonycsiszolatok fedettek, így sem karbonátfestés, sem egyéb múszeres vizsgálat elvégzése nem volt lehetséges a karbonátfázisok pontosabb meghatározása érdekében. Így üregkitöltő, valamint helyettesítő dolomit esetében a morfológiát (sajátalakú romboéderes kristályok) alkalmaztuk elkülönítési bélyegként. Fúrómagminták a tanulmány elkészülése során nem álltak rendelkezésünkre. A vékonycsiszolatokról készült fényképek Olympus BX-41 mikroszkópra szerelt Olympus DP-73 típusú kamerával készültek.

\section{A dorozsmai márvány petrográfiai jellemzói}

A Dorozsma-4, a Dorozsma-7, továbbá a Dorozsma54 fúrások által feltárt márványból készült archív vékonycsiszolatok vizsgálata (I. táblázat) alapján azok karbonát + kvarc + Mg-klorit \pm talk(?) összetételúek, és a nagyon finom - finom szemcseméret-tartományba esnek (I. tábla, $E-H$; II. tábla, A-D). Jellemzően heteroblasztos szövetûek, a szemcsék érintkezésének jellege általában szutúrált, azonban olykor beöblösödő szemcsehatárok szintén megfigyelhetôk. A karbonátszemcsék gyakran unduláló kioltásúak, a deformációs ikerlemezek morfológiai típusai közül mind a négy típus jelen van a mintákban, azonban dominánsan a II. és a IV. típusú ikerlemezek figyelhetôk meg. Egyensúlyi, homeoblasztos szövetú, nagyon finomszemcsés márvány a Dorozsma-54 fúrásban található, ahol az egyenes szemcsehatárral rendelkező szemcsék $120^{\circ}$-os szög mentén érintkeznek egymással, azonban ez a típus csupán egy mintára korlátozódik (II. tábla, $A$ ).

A vizsgált minták általános jellemzője, hogy kisméretû, oldódásos üregeket tartalmaznak, valamint vékony, mikrokristályos vagy tömbös kvarccal kitöltött erek szelik át őket (II. tábla , $E-H$ ). Mind az üregeket, mind az ereket vékony, finomszemcsés, mikrokristályos ( $<5 \mu$ m méretû) karbonátszegély övezi (II. tábla, $G$ és $H$ ). Az oldódásos üregek falán gyakran apró, sajátalakú karbonátkristályok találhatók, amelyek mellett tömbös kvarc tölti ki az üreget (II. tábla, E). Emellett egyes esetekben az üreg falán fenn-nőtt, idiomorf, zónás karbonátásvány (dolomit) figyelhetô meg, olykor ívelt kristálylapokkal (II. tábla, F).

Több mintában a nagyon finomszemcsés $(\sim 15-20 \mu \mathrm{m}$ szemcseméretû) karbonátban mikrokristályos kovahelyettesítés figyelhető meg (III. tábla, $A$ és $B$ ), valamint helyenként 
I. táblázat. A vizsgált minták petrográfiai jellemzői

Table I. Petrographic characteristics of the studied samples

\begin{tabular}{|c|c|c|c|c|c|c|c|}
\hline Fúrás & Minta & Összetétel & Szemcseméret & Szövet & Szemcsehatár & $\begin{array}{c}\text { Deformációs } \\
\text { ikrek }\end{array}$ & Egyéb \\
\hline Do-54 & 27326 & karbonát & nagyon finomszemcsés & homeoblasztos & egyenes & II., IV. & $\begin{array}{l}\text { egyensúlyi szövet } \\
\left(120^{\circ}\right)\end{array}$ \\
\hline Do-54 & 27341 & $\begin{array}{c}\text { karbonát }+Q \mathrm{tz}+\mathrm{Ms}+\mathrm{Mg}- \\
\text { chl }\end{array}$ & $\begin{array}{l}\text { nagyon finom- } \\
\text { finomszemcsés }\end{array}$ & heteroblasztos & $\begin{array}{c}\text { nem } \\
\text { megállapitható }\end{array}$ & II., IV. & $\begin{array}{c}\text { deformációs sáv } \\
\text { oldódási nyomokkal }\end{array}$ \\
\hline Do-54 & $\begin{array}{l}27759 ; \\
27760 ; \\
27761 ; \\
27762\end{array}$ & $\begin{array}{c}\text { karbonát+Qtz+Mg- } \\
\text { chl+Tlc(?) }\end{array}$ & nagyon finomszemcsés & heteroblasztos & $\begin{array}{l}\text { szutúrált, } \\
\text { beöblösödő }\end{array}$ & I., II., IV. & $\begin{array}{l}\text { mikrokristályos és } \\
\text { tömbös kvarccal } \\
\text { kitöltött erek, üregek }\end{array}$ \\
\hline Do-54 & 27764 & $\begin{array}{l}\text { karbonát+ } \\
\text { kova }\end{array}$ & nagyon finomszemcsés & homeoblasztos & $\begin{array}{c}\text { nem } \\
\text { megállapítható }\end{array}$ & - & - \\
\hline Do-54 & $\begin{array}{l}27763 ; \\
27765 ; \\
27776 ; \\
27875 ; \\
27878 \\
\end{array}$ & $\begin{array}{c}\text { karbonát+ } \\
\text { kova+Mg-chl+ms }\end{array}$ & $\begin{array}{l}\text { nagyon finom- } \\
\text { finomszemcsés }\end{array}$ & heteroblasztos & $\begin{array}{l}\text { szutúrált, } \\
\text { esetenként nem } \\
\text { megállapitható }\end{array}$ & $\begin{array}{l}\text { I., II., III., } \\
\text { IV. }\end{array}$ & $\begin{array}{l}\text { finomszemcsés } \\
\text { alapanyagban } \\
\text { mikrokristályos } \\
\text { kovahelyettesités }\end{array}$ \\
\hline Do-7 & $\begin{array}{c}\text { 8-1-d; } \\
\text { 8-1-d (2) } \\
\text { 8-1-d (3) }\end{array}$ & karbonát+Qtz & nagyon finomszemcsés & heteroblasztos & $\begin{array}{c}\text { nem } \\
\text { megállapítható }\end{array}$ & II. & $\begin{array}{c}\text { szigmoidális } \\
\text { karbonát klasztok, } \\
\text { karbonát utáni kvarc } \\
\text { pszeudomorfózák }\end{array}$ \\
\hline Do-4 & $\begin{array}{c}14 ; \\
14-1 ; \\
14-1(2)\end{array}$ & $\begin{array}{c}\text { karbonát+Qtz+Mg- } \\
\text { chl+Tlc (?) }\end{array}$ & finomszemcsés & heteroblasztos & szutúrált & I., II., IV. & $\begin{array}{c}\text { mag-köpeny } \\
\text { szerkezetek, } \\
\text { karbonáthelyettesítés }\end{array}$ \\
\hline
\end{tabular}

az említett finomszemcsés, karbonát, illetve kova alkotta mátrixban nagyméretú, visszaoldott karbonátszemcsék/ klasztok vannak, amelyeken tiszta, zárványmentes továbbnövekedési perem látható (III. tábla, $C-H$ ). Ezen szemcsékben a II. típusú deformációs ikerlemezek jól azonosíthatók (III. tábla, E és $F$ ).

A Dorozsma-4 fúrásban feltárt, egyes részein erôsen átalakult márvány (III. tábla, B) jellegzetessége, hogy a nagyméretú kristályok határán apró, zárványmentes karbonátszemcsék találhatók, továbbá a klasztok határán változó nagyságú, lemezes Mg-klorit is jelen van. A karbonátfázis egyes esetekben a nagyméretú klasztok deformációs ikerlemezeinek helyettesítéseként is megfigyelhetó parányi romboéderes kristályok formájában, ami dolomitra utal (III. tábla, D).

A Dorozsma-7 fúrásból rendelkezésre álló vékonycsiszolatokban mikrokristályos ( $<5 \mu \mathrm{m}$ méretú) alapanyagban nagyméretú, szigmoid alakú karbonátklasztokat figyeltünk meg (III. tábla, G). A klasztok deformációs ikerlemezei (II. típus) jól kivehetők, azonban ezek is átalakultak. A mintában változó méretú, szabálytalan alakú és visszaoldott peremú polikristályos kvarcklasztok szintén találhatók. Ezeket a klasztokat nagyméretú, unduláló kioltású, gyakran alszemcsés szerkezetú, illetve a peremeken helyenként dinamikusan átkristályosodott apró kvarcszemcsék alkotják. A kózetben megfigyelhetốk a polikristályos kvarcklasztok alakjára emlékeztető és azokhoz hasonló nagyságú kőzetrészek, amelyeket sötétszürke, mikrokristályos karbonát alkot. Ezekben kisméretú ( 100-200 $\mu \mathrm{m})$, általában izometrikus, rezorbeált kvarcreliktumok őrződtek meg (III. tábla, $H$ ).

\section{A petrográfiai eredmények értelmezése - diszkusszió}

Márványban az I. típusú ikerlemezek kialakulása $150^{\circ} \mathrm{C}$ alatti hőmérsékleten jellemző, és akár a mintaelőkészítés során is számolnunk kell ezek megjelenésével, így e típust az értelmezés során nem vettük figyelembe. A II. és IV. típusú ikerlemezek jelenléte a dorozsmai márványban már magasabb hőmérsékletú deformációt jelez. Kalcitban a II. típus képződési hőmérsékletére BURKHARD (1993) 150$300{ }^{\circ} \mathrm{C}$-ot becsült, míg FerILL et al. (2004) megállapításai szerint azok $200^{\circ} \mathrm{C}$-nál nagyobb hőmérsékleten alakulnak ki. A IV. morfológiai típusú ikerlemezek kalcitban $250^{\circ} \mathrm{C}$ nál nagyobb hőmérsékletú deformáció során jönnek létre (BURKHARD 1993). Bár a dolomitban hasonló megjelenésú deformációs ikerlemez típusok alakulnak ki, azok jellemzően nagyobb hőmérsékleten képződnek (PASschIER \& TROuw 2005). A vizsgált archív vékonycsiszolatokban a karbonátfázisok megbízható azonosításának hiányában csupán a deformáció minimális hômérséklete becsülhetô meg, mely ezek alapján biztosan meghaladta a $\sim 250{ }^{\circ} \mathrm{C}$-ot.

Jellegzetes csoportot alkotnak a Dorozsma-4 fúrásból származó minták, amelyekben a nagyméretú karbonátklasztok IV. típusú deformációs ikerlemezeit helyettesítő, valamint a klasztok határán elhelyezkedô apró, zárványmentes karbonátszemcsék (valószínúleg dolomit) Mgklorittal és kvarccal társulnak. A szöveti bélyegek alapján valószínúsíthetô, hogy ez a finomszemcsés karbonátperem külső eredetú fluidum átalakító hatásának következménye. A fluidumhatás következtében kis hőmérsékletű dinamikus átkristályosodás is végbemehetett (NÉMETH \& MÁDAI 2004, 
LIU et al. 2002). A vizsgált mintákban előforduló kvarcszemcséken a karbonát-helyettesítéstől eltekintve reakcióperem nem látható, továbbá a talkszemcsék környezetében nem figyelhetôk meg reliktum kvarcszemcsék. Ez arra utal, hogy a talk képződése feltehetôen nem magyarázható a dolomit + kvarc $+\mathrm{H}_{2} \mathrm{O}=$ talk + kalcit $+\mathrm{CO}_{2}$ dekarbonizációs reakcióval (YARDLEY 1989, BUCHER \& GRAPES 2011). A fenti szöveti és ásványtani bélyegek, valamint a mikroerek, oldásos üregek és deformációs sávok szoros szöveti kapcsolata, továbbá a reakciószövet teljes hiánya a zárt rendszerû izokémiai metamorf átalakulással ellentétben nyílt rendszerú, metaszomatikus átalakulást jelez (BARKER 1998). A márványban a kvarc + klorit \pm talk ásványegyüttes megjelenéséért és a karbonátszemcsék mikrokristályos szemcsehalmazokká történő, változó mértékú átkristályosodásáért kis $\mathrm{CO}_{2}$-tartalmú, hidrotermás ( 250-320 $\left.{ }^{\circ} \mathrm{C}\right)$ fluidumok hatása lehet felelős (Boulvais et al. 2006).

A Dorozsma-7 fúrásból leírt szigmoidális megjelenésú, átkristályosodott karbonátklasztokat tartalmazó minták a makroszkópos megjelenéssel szemben képlékeny nyírásos deformációra utalnak. A korábbi II. és IV. típusú ikerlemezek teljesen vagy részlegesen felülíródtak, amelyre relikt szöveti elemek utalnak. A klasztokban a felülbélyegző ikerlemezek sûrúségének növekedésével párhuzamosan azok vastagsága lecsökkent (III. tábla, G), ami az alakváltozás sebességének egyértelmú növekedését jelzi (RYBACKI et al. 2013). RYBACKI et al. (2013) ezt az ikertípust egyszerú nyírásos alakváltozáshoz kötik, ami már $\sim 150{ }^{\circ} \mathrm{C}$-on is kialakulhat. A klasztok erôteljes átalakulása, finomszemcsés halmazokká történô átkristályosodása, a kőzet képlékeny deformációja szintén a fluidum gyengítő hatásával magyarázható (LiU et al. 2002). Ezt megerôsítik az ezekben a szöveti típusokban megfigyelhetô, visszaoldott, karbonáttal helyettesített kvarcszemcsék és kvarc utáni karbonát-pszeudomorfózák (III. tábla, H). A kőzet mikrokristályos alapanyagának irányítatlan szövete, továbbá a szigmoidális klasztokon azonosítható képlékeny nyírásos alakváltozás arra utal, hogy ezekben a mintákban a deformáció fő mechanizmusa a szemcsehatár menti csúszás (grain boundary sliding) lehetett (PASSCHIER \& Trouw 2005). Ez a deformációs mechanizmus mikrokristályos szemcseaggregátumok esetén nagyon hatékony és domináns folyamat, mely fluidum jelenlétében jellemzően diffúziós tömegáramlással társul (KURZ et al. 2000, HERWEGH \& JENNI 2001, PASSCHIER \& Trouw 2005). Feltételezhető tehát, hogy a nagyobb méretú karbonátszemcsék kezdeti dinamikus átkristályosodásának a kőzet-fluidum kölcsönhatás kedvezhetett (RUTTER 1971, NEWMAN \& Mitra 1994, KENNEdy \& LOGAN 1998). A mikrokristályos szemcsehalmazokká történő átkristályosodás során szintén ez segíthette elő a szemcsehatár menti elcsúszás folyamatát, ezáltal a makroszkóposan töréses jellegeket mutató kőzetben mikroléptékben képlékeny alakváltozás jelei ismerhetôk fel (LiU et al. 2002).

A deformáció és az átalakultság mértéke szerint négy kőzettípust különítettünk el a dorozsmai márvány vizsgált mintáiban (6. ábra). Az elsô csoportot a finomszemcsés, heteroblasztos szövetû, ,üdének” tekinthetô változat alkotja (II. tábla , B). Az átalakulás alapján a második csoportot a Mg-klorit + kvarc \pm talk szemcséket tartalmazó, a karbonátszemcsék peremén megjelenő, finomszemcsés köpennyel rendelkező minták képezik (III. tábla, $E$ és $F$ ). Az átalakulás mértékének további növekedésével (3. típus) az eredeti karbonátszemcsék és a mátrix finomszemcsés halmazzá történő átkristályosodása, továbbá a kvarc $\pm \mathrm{Mg}$-klorit megjelenése jellemző (III. tábla B). A leginkább átalakult mintákat (4. típus) a teljesen mikrokristályos szemcsékből álló, mikrokristályos kvarcot $\pm \mathrm{Mg}$-kloritot és néhol átkristályosodott karbonát-szigmoidokat tartalmazó kőzetváltozatok képviselik (III. tábla, $G)$. A felsorolt kőzetváltozatok döntő része
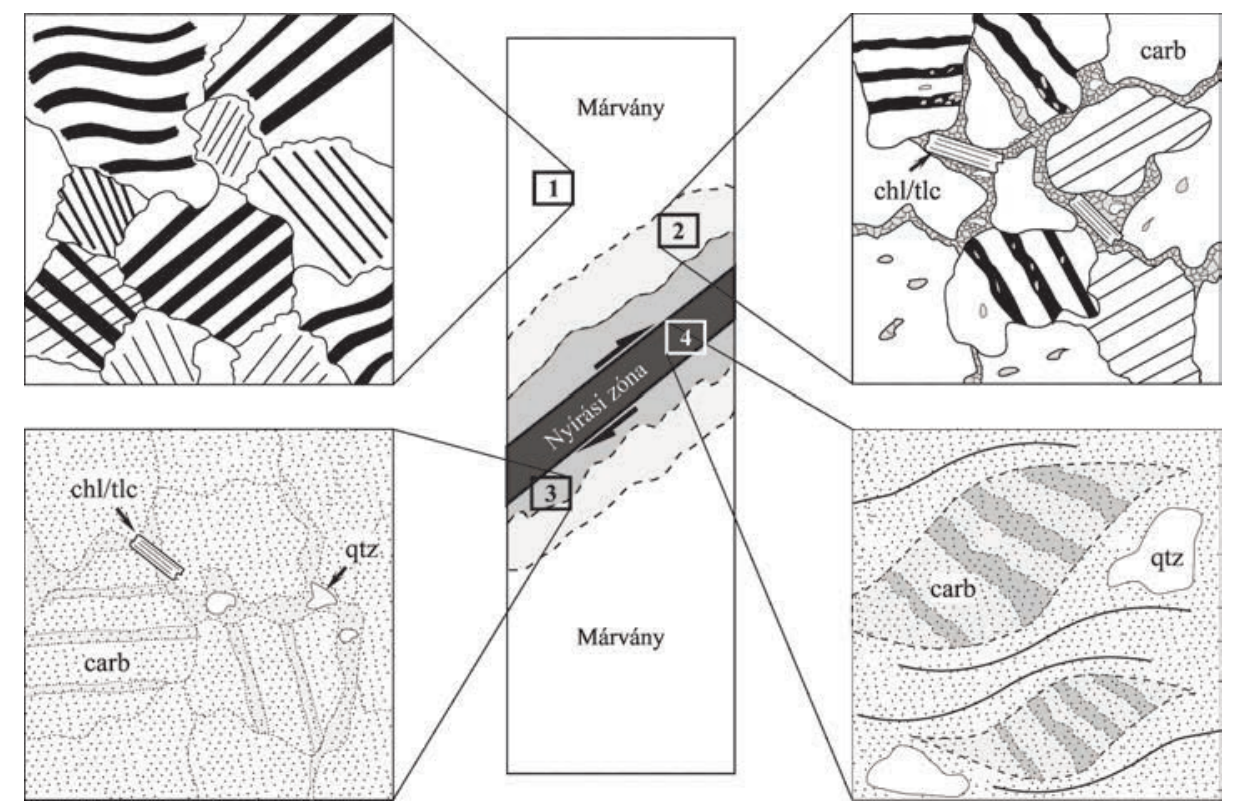

6. ábra. A dorozsmai márványban elkülönitett szöveti típusok sematikus, mezo- és mikroléptékủ ábrázolása egy kisléptékű nyírási zónától távolodva. Az 1. típus az „üde” márványokat képviseli, a 2. típus a karbonátklasztok között jelenlevő Mg-kloritot és talkot, a karbonátkristályokon apró zárványmentes köpenyt tartalmazó szövettípust ábrázolja. A 3. kategória a mikrokristályos kőzetváltozatokat képviseli, a 4. szöveti típus a nagyon finomszemcsés karbonátból álló mátrixban karbonát szigmoidokat és mikrokristályos kvarcot tartalmazó kőzetváltozat. Rövidítések: $\mathrm{chl}=\mathrm{Mg}$-klorit; $\mathrm{tlc}=$ talk; $\mathrm{qz}=$ kvarc; $\mathrm{carb}=$ karbonát

Figure 6. Schematic illustration of the characteristic marble textures with increasing distance from a small scale shear zone in the Dorozsma marble; meso- and micro scale. Type 1: "unaltered” marble; Type 2: marble showing core-mantle structures with the appearance of Mg-chlorite and talc in the matrix; Type 3: marble with pervasive grain size reduction and microcrystalline pseudomorphs after larger carbonate grains; Type 4: very fine-grained marble with sygmoidal carbonate grains and microcrystalline quartz in the matrix. Abbreviations: $c h l=M g$-chlorite; tlc = talc; qz =quartz; carb = carbonate 
kisléptékben, egy mintán belül is megfigyelhetố a Dorozsma-54 fúrásban (III. tábla, C), ahol a deformációs sávtól távolodva azonosítható szöveti típusok a nagyobb léptékú szöveti csoportoknak feleltethetók meg. Ez alapján feltételezhetô, hogy az egyedi mintákhoz hasonlóan, a fenti szöveti kategóriák eltérố szövetfejlődésú, és ilyen módon egy nagyobb léptékú deformációs zónától eltérő távolságra elhelyezkedő mintapontokat képviselhetnek (6. ábra). Meg kell azonban jegyeznünk, hogy a protolit eredeti szövetéről nem áll rendendelkezésünkre információ, tehát annak átöröklött hatását a fenti értelmezésben nem tudtuk figyelembe venni.

A minták petrográfiai vizsgálata alapján két deformációs fázis különíthetô el. Az elsô azonosítható deformációs eseményhez $\left(D_{1}\right)$ a szutúrált szemcsehatárok, valamint a mintákban általánosan megjelenô II. és IV. típusú deformációs ikerlemezek tartoznak. A mikroszöveti bélyegek alapján a $\mathrm{D}_{1}$ deformációs esemény nagy, $250^{\circ} \mathrm{C}$-ot biztosan meghaladó hőmérsékleten zajlott. Ezzel szemben a $\mathrm{D}_{1}$ eseményt felülíró $\mathrm{D}_{2}$ deformációs fázis kis hőmésékleten mehetett végbe, amelyhez fluidumhatás társult. Erre utalnak a Dorozsma-4 fúrásból leírt dinamikus átkristályosodást mutató minták, valamint a Dorozsma-7 fúrásban megjelenő szigmoidális karbonátklasztok a mikrokristályos alapanyagban. A dorozsmai márványt érintő deformációs események, illetve az általunk feltárt metaszomatikus folyamat kristályos aljzaton belüli korrelációjához azonban további vizsgálatok szükségesek.

A dorozsmai márványban megfigyelhetô oldódásos üregek falán fenn-nôtt, görbült kristálylapokkal határolt, zónás nyeregdolomitokhoz hasonló kristályokat írtak le GARAGULY et al. (2016, 2017) az üllési és mórahalmi fúrások által harántolt triász Szegedi Dolomit Formációból, amely a Szegedi-medence legáltalánosabban elterjedt mezozoos képződménye, és az előfordulási területének jelentős részén — tektonikusan — közvetlenül a kristályos aljzatra települ (BÉRCZI-MAKK 1986). A fluidumzárványok mikrotermometriai vizsgálata során kapott homogenizációs hőmérsék-

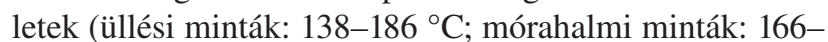
$219^{\circ} \mathrm{C}$ ), valamint a stabil szén- és oxigén-izotópos eredmények alapján GARAGULY et al. (2016) magmás, metamorf vagy ezekkel keveredett, medence eredetú fluidumokból feltételezik a nyeregdolomit kristályosodását. A dorozsmai márvány és a Szegedi Dolomit feltételezett hidrotermális átalakulásának célzott kutatása az aljzati képződmények közötti fluidum-evolúció feltárását segítheti elő.

Korábban LELKES-FELVÁRI et al. (2005) a kőzet ásványos összetétele alapján három márványtípust különítettek el a területen: tisztán kalcit, tisztán dolomit és talk + Mg-klorittartalmú márványt. Megfigyeléseink alapján úgy gondoljuk, hogy kizárólag az összetétel alapján a genetikai csoportok nem különíthetốk el a vizsgált mintákban. A petrográfiai vizsgálatok eredménye alapján azok csoportosítását - az ásványos összetétel figyelembevételével - elsődlegesen szöveti alapon javasoljuk. LeLKES-FELváRI et al. (2005) által a kalcitból és a dolomitból álló márványban leírt szemcsehatárvándorlásos dinamikus átkristályosodás bélyegei mind a Dorozsma-4, mind a Dorozsma-54 fúrás mintáiban megfigyelhetők (I. tábla, $E$ és $H$, II. tábla, $B$ és $G$, III. tábla F). Az M. Tо́тн (2008) által megállapított kis hőmérsékletú töréses deformáció jelei főként makroszkópos léptékben jellemző́k, a mikroszkópos vizsgálatok során a mintákban képlékeny deformációra utaló bélyegek azonosíthatók. A kristályplasztikus deformációs szerkezetek jellegei alapján feltételezhetô, hogy a képlékeny alakváltozás kis hőmérsékleten, vélhetően erőteljes fluidumhatás eredményeként ment végbe (Newman \& Mitra 1994, Kennedy \& Logan 1998, KurZ et al. 2000, Herwegh \& Jenni 2001, Liu et al. 2002, PASSChIER \& TROuW 2005).

\section{Regionális kitekintés — korrelációs lehetóségek a Tiszai-fö́egységben}

Hazánk területén a Tiszai-fóegység kristályos aljzatából csupán néhány területen dokumentáltak márvány előfordulást. A Villány-Bihari-zónában mélyült Sáránd-1 fúrás kristályos kőzetek (gneisz, csillámpala) alatt középsô-triász palás mészkőből, dolomitból és cippolino jellegú kalcit- és dolomárványból álló kózetegyüttest tárt fel a Mecseki- és a Villány-Bihari-zóna határától néhány kilométerre délre (ÁRKAI et al. 1998, BÉRCZINÉ et al. 2004). E karbonátok szerkezetileg a mélyebb helyzetú Mecsekiegységbe tartoznak. A Dorozsmai Komplexumban ismert, maximum néhány tíz méter vastagságú, erősen tektonizált márvány (LelKES-Felvári et al. 2005, М.Tóth 2008) mellett a Dél-Dunántúl kristályos aljzatában, a Baksai Komplexumban írtak le kalcit- és dolomárványt, amelyet az említett komplexumon belül két rétegcsoportba, egy felső és egy alsó márványos rétegcsoportba soroltak (SZEDERKÉNYI 1996, FinToR et al. 2005). Kristályos mészkő, valamint márvány található a korábban Ófalui Formáció Kristályos Mészkő Tagozat néven ismert (FüLÖP 1994), jelenleg a Juhhodályvölgyi Mészkő Formációba sorolt képződményben, amely az Aranyos-völgy jobb és bal oldalán, illetve a Juhhodály-völgyben tanulmányozható (GULÁCSI \& KOROKNAI 2009).

Míg az Alföld kristályos aljzata felszíni kibúvások hiányában csupán mélyfúrások, karotázs szelvények és szeizmikus szelvények révén tanulmányozható, a Tiszai-főegység keleti részét képező (HAAS \& PÉRó 2004, HAAS et al. 2010) Északi-Erdélyi-középhegységben számos felszíni feltárás található. Itt több márvány előfordulást is ismerünk, amelyek közül a legjelentősebbek a Kisbihari/Biharia-takarórendszerben találhatóak. Ezeket a kvarcitból, dolomárványból és márványból felépülő kôzetegyütteseket korábban a Kisbihari/Biharia-takaró prealpi polimetamorf kristályos aljzatára települő, bizonytalan proterozoos-paleozoos korú üledékes fedőnek, míg zöldpala fáciesú metamorfózisuk korát variszkuszinak tartották (MÂRZA 1965, LuPU et al. 1966). Kounov \& SCHMID (2013) szerkezeti modellje szerint a Kisbihari/Biharia-takarórendszer a Gyalui-havasok (Munţii Gilăului) és a Torockói-hegység (Munții Trascăului) területén három takaróra osztható: a Kisbihari/ Biharia-, az Aranyosbányai/Baia de Arieş- és a Vidalyi/ Vidolm-takaróra. 
REISER et al. (2017a) megállapították, hogy a kérdéses márvány kőzettestek mindhárom takaróban megtalálhatók, és a prealpi polimetamorf kristályos képződményekre települó metamorfizálódott mezozoos összleteknek tekinthetők.

REISER et al. (2017b) szerint a Kisbihari/Biharia-takaró keleti részén számos, a polimetamorf kőzetekbe települő és rétegtani szintben követhetô, sárgásbarna dolomárvány lencse ismert. Többnyire halványvörös-rózsaszín kvarcittal együtt fordulnak elő, és kvarcerek járják át őket. A dolomárványra dinamikusan rekrisztallizált, finomszemcsés, heteroblasztos szövetú, $120^{\circ}$-os szemcseérintkezési szögek jellemzőek, a deformációs ikerlemezek morfológiai típusai közül a II., a III. és a IV. típus van jelen a kőzetben.

A Bélavári-egység (Vulturese-Belioara Unit) a Kisbihari/Biharia- és az Aranyosbányai/Baia de Arieș-takarók tektonikus érintkezési övében húzódó, zöldpala fáciesú metaüledékekből álló összlet (BALINTONI et al. 1987), amelyben - metakonglomerátum, kvarcit, szericitpala mellett - fekete, grafitos dolomit, tömeges vöröses-sárgás színú dolomit, továbbá mállottan vöröses, szericites, lemezes márvány és egy $\sim 350 \mathrm{~m}$ vastag világosszürke, fehér, részben dolomitos márvány van jelen (REISER et al. 2017b).

REISER et al. (2017b) alapján a Bélavári-egységtől (Vulturese-Belioara Unit) 20-30 km-re, Topánfalva (Câmpeni) községtől közvetlenül keletre, az Aranyosbányai/Baia de Arieş-takaróban a bizonytalan települési helyzetú Sohodoli Márvány breccsás, kataklázitos átmeneti zónán keresztül egy fekete kvarcitból és grafitos palából álló összletre települ. A márvány fehér és szürke színú, jól rétegzett, vékony vöröses színú közbetelepülésekkel váltakozik, erősen redôzött, kvarclencséket tartalmaz. A mikroszöveti bélyegek alapján a márvány szemcsehatár-vándorlásos dinamikus rekrisztallizációt mutat, a deformációs ikerlemezek közül az I., a III. és a IV. típus figyelhetố meg. IANOVICI et al. (1976) szórványos crinoidea vázelemek jelenléte alapján pontosabban meg nem határozott mezozoos üledéknek gondolják. Aranyosbánya (Baia de Arieş) városától $~ 5$ km-re, DK-re durvakristályos, fehér és sárgás márványból álló, az előbbieknél lényegesen kisebb kiterjedésú, lencseszerú kőzettestek ismertek az Aranyosbányai/Baia de Arieş-takaró kristályos tömegében, melyek kora feltételesen szintén mezozoos (KouNOv \& SCHMID 2013).

A legmagasabb helyzetú, Vidalyi/Vidolm-takaró tetején, a Marosi-öv ofiolitjaival tektonikusan érintkezve találunk több, szürke kalcitmárvány és sárgásfehér dolomárvány testet, amelyek egy kvarcitos konglomerátummal és fekete kvarcitos palával induló rétegsor részét képezik. A kalcitmárvány centiméteres-méteres rétegzettséget mutat, fillit és kvarcit közbetelepülésekkel, míg a dolomárvány tömeges (ReISER et al. 2017b). A márvány durvaszemcsés, homeoblasztos szövetú, szutúrált szemcsehatárokkal. A deformációs ikerlemezek típusai közül az I., a II. és a IV. típusok vannak jelen, a mikroszöveti bélyegek alapján pedig szemcsehatárvándorlásos rekrisztallizáció mutatható ki, amelynek hômérsékletét $250-350^{\circ} \mathrm{C}$-ra becsülik (REISER et al. 2017b). KounOv \& SCHMID (2013) hipotetikusan a vidalyi márványokat is mezozoos korúnak tekintik.

A Hegyes-hegység (Munții Highişului) ÉNy-i szélén a Kovászi (Covasinț), Világos (Şiria) és Almásegres (Agrişu Mare) közötti területen a Pajzsi Komplexumhoz (Paiuşeni Complex) kapcsolódva, intenzíven nyírt, milonitosodott metamagmatitok és metaüledékes kózetek között alárendelten néhány méteres nagyságrendú (dolo-)márvány lencsék helyezkednek el (PAPIU \& GENEA 1965), amelyekról publikált adat nem érhető el.

A nagyszerkezeti besorolást tekintve a Dorozsma környéki aljzatot a Tiszai-fóegységen belül a Békés-Codruizóna alkotja (HAAS et al. 2010), ami ÉNy-on a VillányBihari-zónára tolódott rá. Egyes értelmezések szerint azonban az Algyői-aljzatmagaslat kristályos képződményei és azzal analóg szerkezeti helyzetúnek tekintett Dorozsmai Komplexum - már a Kisbihari/Biharia-zóna része LeLKESFeLVÁri et al. 2005, Schmid et al. 2008). A fenti regionális kitekintés felhívja a figyelmet arra, hogy a Tiszai-főegység magyarországi részén található márványképződmények (különösen a dorozsmai márvány) komplex, átfogó petrográfiai és geokémiai vizsgálata új, független eszközt biztosíthat számunkra mind e metamorf kőzettestek megismeréséhez, mind a lokális és a regionális korrelációs kérdések tisztázásához.

\section{Összefoglaló következtetések}

Munkánk során összegeztük a márványok alapvető petrográfiai leírásához szükséges legfontosabb szempontokat a nemzetközi szakirodalom alapján, amelyet a Dorozsma-4, Dorozsma-7 és Dorozsma-54 fúrások által harántolt márványzónából készült archív vékonycsiszolatok petrográfiai vizsgálata során alkalmaztunk.

A megfigyeléseink alapján a dorozsmai márványt karbonát + kvarc + Mg-klorit \pm talk(?) összetételú, finomszemcsés, jellemzően heteroblasztos szövetú márvány építi fel, amelyre dominánsan szutúrált, illetve beöblösödő szemcsehatárok jellemzőek, a deformációs ikerlemezek morfológiai típusai közül döntően az I., a II. és a IV. típus van jelen. A mintákban átalakult kőzetváltozat is megfigyelhetô, továbbá nagyméretú, szigmoid-alakú karbonátklasztok és szabálytalan alakú, visszaoldott peremú, polikristályos kvarcklasztok is találhatók a mikrokristályos alapanyagban. Helyenként a nagyméretú karbonátszemcsék deformációs ikerlemezeit kisméretú, zárványmentes karbonátszemcsék (dolomit) helyettesítik, amelyek a szemcsék szegélyén is megtalálhatók lemezes Mg-klorittal együtt.

A szöveti bélyegek alapján feltételezhetô, hogy a jelenlegi ásványos összetétel és mikroszerkezet kialakulásában legalább két jelentôs deformációs esemény kapott szerepet. A korábbi fázis $250{ }^{\circ} \mathrm{C}$-ot biztosan meghaladó hőmérsékleten zajlott, majd ezt követően egy kis hőmérsékletú deformációhoz kapcsolódó fluidumhatás (metaszomatózis) is 
jelentôs szerepet játszhatott, amelynek eredményeként képlékeny nyírásos alakváltozás és kis hőmérsékletú dinamikus átkristályosodás jöhetett létre a kôzetben.

A dorozsmai márvány részletes petrográfiai-petrológiai és geokémiai reambulációja egy későbbi kutatásban olyan eredményeket szolgáltathat, amelyek elősegíthetik az Alföld aljzati képző́dményeinek korrelációját. A vizsgált Dorozsmai Komplexum regionális földtani jelentőségét nyomatékosítja, hogy a legújabb kutatási eredmények bizonyították a márvány- és dolomitmárvány kifejlődések protolitjának triász korát a Kisbihari/Biharia-zónában (Erdélyiközéphegység), ahol a képződmények feküjében a Jakabhegyi Homokkő dél-alföldi kifejlódéséhez hasonló kvarcdús metakonglomerátum jelenik meg.

\section{Köszönetnyilvánítás}

Ezúton szeretnénk köszönetet mondani M. TóTH Tivadarnak a munkánk elkészüléséhez szükséges feltételek biztosításáért. Továbbá köszönetet mondunk a MOL Nyrt-nek (külön köszönet illeti KIss Balázst, AmRAN Ahmedet és VOLTER Györgyöt) a Dorozsma környéki fúrásokból származó archív vékonycsiszolatok rendelkezésünkre bocsátásáért, valamint jelen tanulmány publikálásának engedélyezéséért. Köszönettel tartozunk KoROKNAI Balázsnak és MÁDAI Ferencnek az alapos és részletes lektorálásért, gondolatébresztó megjegyzéseikért. Ez a munka a K 108375 nyilvántartási számú projekt keretein belül valósult meg, a Nemzeti Kutatási Fejlesztési és Innovációs Alapból biztosított támogatással.

\section{Irodalom — References}

Abu-Jaber, N., Al-SAAD, Z., Shiyyab, A. \& Degryse, P. 2012: Provenance of white marbles from the Nabatean sites of Qasr al Bint and the collonaded street baths at Petra, Jordan. — Mediterranean Archaeology and Archaeometry 12/1, 21-29.

Al-Bashaireh, K. \& Al-Housan, A., Q. 2015: Provenance investigation of white marbles of chancel screens from Rihab Byzantine churches, northeast Jordan. — Journal of Cultural Heritage 16, 591-596. https://doi.org/10.1016/j.culher.2014.10.002

Antonelli, F., Lapuente, M. P., Dessandier, D. \& Kamel, S. 2015: Petrographic characterization and provenance determination of the crystalline marbles used in the roman city of Banasa (Morocco): New data on the import of Iberian marbles in roman North Africa. - Archaeometry 57, 405-425. https://doi.org/10.1111/arcm.12099

ÁrKAI, P., BÉRCZI-MAKK, A. \& HAJdú, D. 1998: Alpine prograde and retrograde metamorphisms in an overthrusted part of the basement, Great Plain, Pannonian Basin, Eastern Hungary. — Acta Geologica Hungarica 41/2, 179-210.

Balintoni, I., Pu te, A. \& Stan, R., 1996: The Codru nappe system and the Biharia Nappe System: A comparative argumentation. Studia Universitatis Babeş Bolyai, Geologia 41, 101-113.

BARBER, D. J. \& Wenk, H. R. 1979: Deformation twinning in calcite, dolomite, and other rhombohedral carbonates. — Physics and Chemistry of Minerals 5, 141-165. https://doi.org/10.1007/bf00307550

BARKer, A. J. 1998: Introduction to Metamorphic Textures and Microstructures. - Stanley Thornes Ltd, Cheltenham, 263 p. https://doi.org/10.4324/9781315831626

BÉRCZI-MAKK, A. 1986: Mesozoic formation types of the Great Hungarian Plain. — Acta Geologica Hungarica 29, $261-282$.

BérCZinÉ MAKK, A., KonRád Gy., RÁLISChné FelgenhaUer E. \& TöröK, Á. 2004: Tiszai egység. — In: HaAs J. (szerk.): Magyarország geológiája, Triász. - ELTE Eötvös Kiadó, Budapest, 384 p.

BEst, M. G. 2003: Igneous and metamorphic petrology. — Blackwell Publishing, Berlin, 749 p.

Borghi, A., Vaggelli, G., Marcon, C. \& Fiora, L. 2009: The Piedmont white marbles used in antiquity: an archeometric distinction inferred by minero-petrographic study and C-O stable isotope study. — Archaeometry 51, 913-931. https://doi.org/10.1111/j.14754754.2008.00447.x

Boulvais, P., De Parseval, P., D’Hulst, A. \& Paris, P. 2006: Carbonate alteration associated with talc-chlorite mineralization in the eastern Pyrenees, with emphasis on the St. Barthelemy Massif. — Mineralogy and Petrology 88, 499-526. https://doi.org/ 10.1007/s00710-006-0124-X

Brilli, M., Guistini, F., Conte, A. M., Mercadal, P. M., Quarta, G., Plumed, H. R., Scardozzi, G. \& Belardi, G. 2015: Petrography, geochemistry, and cathodoluminescence of ancient white marble from quarries in the southern Phrygia and northern Caria regions of Turkey: Considerations on provenance discrimination. — Journal of Archeological Sciences, Report 4, 124-142. https://doi.org/ 10.1016/j.jasrep.2015.08.036

BucheR, K. \& Grapes, R. 2011: Petrogenesis of metamorphic rocks. — Springer-Verlag, Berlin, Heidelberg, 428 p. https://doi.org/ 10.1007/978-3-540-74169-5

BuRKHARD, M. 1993: Calcite twins, their geometry, appearance and significance as stress-strain markers and indicators of tectonical regime: a review. - Journal of Structural Geology 15, 351-368. https://doi.org/10.1016/0191-8141(93)90132-t

Capedri, S., Venturelli, G. \& Photiades, A. 2004: Accessory minerals and ${ }^{18} \mathrm{O}$ and ${ }^{13} \mathrm{C}$ of marbles from the Mediterranean area. Journal of Cultural Heritage 5, 27-47. https://doi.org/10.1016/j.culher.2003.03.003

CsÁszÁr G. 2005: Magyarország és környezetének regionális földtana I. Paleozoikum-Paleogén. — ELTE Eötvös Kiadó, Budapest, 328 p.

Ebert, A., Herwegh, M., Berger, A. \& Pfiffner, A. 2008: Grain coarsening maps for polymineralic carbonate mylonites: A calibration based on data from different Helvetic nappes (Switzerland). — Tectonophysics 457, 128-142. https://doi.org/10.1016/j.tecto. 2008.05.007

Ferill, D. A., Morris, A. P., Evans, M. A., Burkhard, M., Groshong, R. H. \& Onasch, C. M. 2004: Calcite twin morphology: a lowtemperature deformation geothermometer. - Journal of Structural Geology 25, 1521-1529. https://doi.org/10.1016/j.jsg. 2003.11.028 
FinTOR K., SCHUBERT F. \& M. TóTH T. 2008: Hiperszalin paleofluidum-áramlás nyomai a Baksai Komplexum repedésrendszerében. — Földtani Közlöny 138/3, 257-278.

FÜLÖP J. 1994: Magyarország geológiája, Paleozoikum II. — Akadémiai Kiadó, Budapest, 447 p.

Garaguly I., Varga A., Raucsik B., Schubert F., Czuppon Gy. \& Halász-Szabó K. 2016: Mélybetemetődési és telogenetikus átalakulások nyomai a Szegedi Dolomit Formációban. — In: BENKó Zs. (szerk.) 2016: Itt az idő! Kőzettani-Geokémiai folyamatok és azok geokronológiai vonatkozásai. MTA ATOMKI, Debrecen, 124 p.

GARAGUly I., RAUCSIK B., VARGA A. \& SChUBERT F. 2017: Középső-triász dolomitok képződésének története és töréses deformációja a Szegedi-medence területén. — Földtani Közlöny 147/1, 39-60. https://doi.org/10.23928/foldt.kozl.2017.147.1.39

Gorgoni, C., LazZarini, L., Pallante, P. \& Turi, B. 1998: An updated and detailed mineropetrographic and C-O stable isotopic reference database for the main Mediterranean marbles used in antiquity. - Proceedings of the $V^{\text {th }}$ ASMOSIA Conference, 1-25.

GulÁCSI, Z. \& KoRoKNAI, B. 2009: Alsó-paleozoikum, Ófalui formáció csoport. — In: BALLA, Z. \& GyALOG, L. (eds): A Mórágyi-rög északkeleti részének földtana. - MÁFI, Budapest, 283 p.

HAAS J. \& BUDAI T. 2010: Magyarország prekainozoos medencealjzatának földtana. Magyarázó „Magyarország pre-kainozoos földtani térképéhez” (1:500 000). — Magyar Földtani és Geofizikai Intézet, Budapest, 71 p.

HAAS, J. \& Péró, Cs. 2004: Mesozoic evolution of the Tisza Mega-unit. — International Journal of Earth Sciences 93, $297-313$. https://doi.org/10.1007/s00531-004-0384-9

Haas, J., Kovács, S., Karamata, S., Sudar, M., Gawlick, H. J., Grădinaru, E., Mello, J., Polák, M., Péró, Cs., Ogorelec, B. \& Buser, S., 2010: Jurassic environments in the Circum-Pannonian region. — In: VozÁR, J., Ebner, F., VozÁrová, A., HaAs, J., Kovács, S., Sudar, M., BIElik, M., PÉró, Cs. (eds): Variscan and Alpine terranes of the Circum-Pannonian Region. Geological Institute, SAS, Bratislava. Chapter 5, 157-202.

HeRWEGH, M. \& JeNNI, A. 2001: Granular flow in polymineralic rocks bearing sheet silicates: new evidence from natural examples. Tectonophysics 332, 309-320. https://doi.org/10.1016/s0040-1951(00)00288-2

Ianovici, V., Borco, M., Bleahu, M., Patrulius, D., Lupu, M., Dimitrescu, R. \& Savu, H. 1976: Geology of the Apuseni Mountains. Academia Republicii Socialiste România, Bucureşti. 631 p.

Iordanidis, A., Charalampides, G., Garcia-Guinea, J., Correcher, V. \& Karamitrou-Mentessidi, G. 2008: A preliminary provenance study of marble artefacts from Aiani, ancient upper Macedonia, Greece. - Geoarchaeology and Archaeomineralogy: Proceedings of the International Conference, 103-107.

JANSSEN, C., RyBACKI, E. \& DRESEN, G. 2007: Critical re-evaluation of calcite twins as a low-temperature deformation geothermometer. - Geophysical Research Abstract 9, EGU2007-A-02228.

Karaca, Z., Hacimustafaoglu, R. \& GöKce, M., V. 2015: Grain properties, grain-boundary interactions and their effects on the characteristics of marbles used as building stones. — Construction and Building Materials 93, 166-171. https://doi.org/10.1016/ j.conbuildmat.2015.05.023

Kennedy, L. A. \& Logan, J. M. 1998: Microstructures of cataclasites in a limestone-on-shale thrust fault: implication for lowtemperature recrystallization of calcite. — Tectonophysics 295, 167-186. https://doi.org/10.1016/s0040-1951(98)00119-x

KounOv, A. \& ScHMID, S. 2013: Fission-track constraints on the thermal and tectonic evolution of the Apuseni Mountains (Romania). International Journal of Earth Sciences 102, 207-233. https://doi.org/10.1007/s00531-012-0800-5

Kovács, S., HaAs, J., CsászÁr, G., SzederkénYi, T., BudA, Gy. \& NAgymarosy, A. 2000: Tectonostratigraphic terranes in the preNeogene basement of the Hungarian part of the Pannonian area. - Acta Geologica Hungarica 43/3, 225-328.

KoroKnaI B. 2004: Tektonometamorf fejlődés az Upponyi- és Szendrői-paleozoikumban. — Kézirat, Doktori értekezés, ELTE, 239 p.

Kurz, W., Neubauer, F., Unzog, W., Genser, J. \& Wang, X. 2000: Microstructural and textural development of calcite marbles during polyphase deformation of Penninic units within the Tauern Window (Eastern Alps). — Tectonophysics 316, 327-342. https://doi.org/ 10.1016/s0040-1951(99)00257-7

LazZarini, L., Moschini, G. \& Stievano, B. M. 1980: A contribution to the identification of Italian, Greek and Anatolian marbles through a petrological study and the evaluation of $\mathrm{Ca} / \mathrm{Sr}$ ratio. - Archaeometry 22, 173-183. https://doi.org/10.1111/j.14754754.1980.tb00940.x

LiU, J., WALter, J. M. \& Weber, K. 2002: Fluid-enhanced low-temperature plasticity of calcite marble: Microstructures and mechanisms. — Geology 30/9, 787-790. https://doi.org/10.1130/0091-7613(2002)030<0787:feltpo $>2.0 . c 0 ; 2$

Lelkes-Felvári, Gy., Frank, W., Schuster, R. \& SASSI, R. 2005: Metamorphic history of the Algyő High (Tisza Mega-unit, basement of Great Hungarian Plain) - a counterpart of crystalline units of the Koralpe-Wölz nappe system (Austroalpine, Eastern Alps). Acta Geologica Hungarica 48/4, 371-394. https://doi.org/10.1556/ageol.48.2005.4.2

Less Gy., Kovács S., Szentpétery I., Grill J., Róth L., Gyuricza Gy., SÁsdi L., Piros O., Réti Zs., Elsholz L., Árkai P., NaGy E., Borka Zs., Harnos J. \& Zelenka T. 2006: Az Aggtelek-Rudabányai-hegység földtana. — MÁFI, Budapest, 92 p.

Lupu, M., Borcoş, M. \& Dimitrescu, R. 1966: Nota explicativa de harta geologică a Republicii Socialiste România. Foaia 1:200.000 Turda. — Comitetul de Stat al Geologiei Institutul Geologic, Bucureşti, 42 p.

MÂRZA, I. 1965: Unitatea petrografică i paleostratigrafică a masivelor de carbonați metamorfici: Vulturese-Scărisoara-Leurda (Bazinul Arie ului). - Analele Universității Bucureşti: Seria tiințele naturii. Geologie Geografie 14, 9-17.

Melfos, V., Voudouris, P., Papadopoulou, L., Sdrolia, S. \& Helly, B. 2010: Mineralogical, petrographic and stable isotopic study of ancient white marble quarries in Thessaly, Greece - II. Chasanbali, Tempi, Atrax, Tisaion Mountain. - Bulletin of the Geological Society of Greece XLIII/2, 845-855. http://dx.doi.org/10.12681/bgsg.11250

Moens, L., Roos, P., De Rudder, J., De Paepe, P., Van Hende, J. \& Waelkens, M. 1988: A multi-method approach to the identification of white marbles used in antique artifacts. - In: HERz, N. \& WAELKENS, M. (eds): Classical marble: Geochemistry, technology, trade. Springer, Dordrecht, 464 p. https://doi.org/10.1007/978-94-015-7795-3 
M. Tóтн T. 2008: Repedezett, metamorf fluidumtárolók az Alföld aljzatában. — Doktori értekezés, MTA, 399 p.

NÉMETH N. \& MÁDAI F. 2004: Korai fázisú képlékeny deformációs elemek a Bükk hegység keleti részének mészköveiben II. mikroszerkezeti jellemzők. — Földtani Közlöny 134/1, 1-28.

Newman, J. \& Mitra, G. 1994: Fluid-influenced deformation and recrystallization of dolomite at low temperatures along a natural fault zone, Mountain City window, Tennesse. — Geological Society of America Bulletin 106, 1267-1280. https://doi.org/10.1130/00167606(1994)106<1267:fidaro >2.3.co;2

Papiu, V. C. \& GheneA, C. 1965: Nota explicativa de harta geologică a Republicii Socialiste România. Foaia 1:200.000 Arad. — Comitetul de Stat al Geologiei Institutul Geologic, Bucureşti, 25 p.

Passchier, C. S. \& Trouw, R. A., J. 2005: Microtectonics. — Springer Verlag, Berlin Heidelberg, 366 p. https://doi.org/10.1007/978-3662-08734-3

PoLIKRETI, K. 2007: Detection of ancient marble forgery: Techniques and limitations. — Archaeometry 49, 603-619. https://doi.org/ 10.1111/j.1475-4754.2007.00325.x

PolikREti, K. \& MANiatis, Y. 2002: A new methodology for the provenance of marble based on EPR spectroscopy. - Archaeometry 44, 1-21. https://doi.org/10.1111/1475-4754.00040

Reiser, M.K., Schuster, R., Spikings, R., Tropper, P. \& Fügenschuh, B. 2017a: From nappe stacking to exhumation: Cretaceous tectonics in the Apuseni Mountains (Romania). — International Journal of Earth Sciences 106, 659-685. https://doi.org/ 10.1007/s00531-016-1335-y

ReISER, M.K., Schuster, R., Tropper, P. \& FÜGenschuh, B. 2017b: Constraints on the depositional and tectonometamorphic evolution of marbles from the Biharia Nappe System (Apuseni Mountains, Romania). — Geologica Carpathica 68/2, 147-164. https://doi.org/10.1515/geoca-2017-0012

Ricca, M., Belfiore, C. M., Ruffolo, S. A., Barca, D., Buergo, M. A. D., Crisci, G. M. \& La Russa, M. F. 2015: Multi-analytical approach applied to the provenance study of marbles used as covering slabs in the archeological submerged site of Baia (Naples, Italy): The case of the „Villa con ingresso a protiro”. — Applied Surface Science 357, 1369-1379. https://doi.org/ 10.1016/j.apsusc.2015.10.002

RUTTER, E. H. 1971: The influence of interstitial water on the rheological behaviour of calcite rocks. — Tectonophysics 14, 13-33. https://doi.org/10.1016/0040-1951(72)90003-0

Rybacki, E., Evans, B., Janssen, C., Wirth, R. \& Dresen, G. 2013: Influence of stress, temperature, and strain on calcite twins constrained by deformation experiments. — Tectonophysics 601, 20-36. https://doi.org/10.1016/j.tecto.2013.04.021

Schmid, S. M., Bernoulli, D., Fügenschuh, B., Matenco, L., Schefer, S., Schuster, R., Tischler, M. \& Ustaszewski, K. 2008 : The Alpine-Carpathian-Dinaridic orogenic system: correlation and evolution of tectonic units. - Swiss Journal of Geosciences 101, 139-183

SZEDERKÉNYI T. 1984: Az Alföld kristályos aljzata és földtani kapcsolatai. — Doktori értekezés, MTA, 183 p.

SZEDERKÉNYI, T. 1996: Metamorphic formations and their correlation in the Hungarian part of Tisia Megaunit (Tisia composite terrane). - Acta Mineralogica Petrographica 37, 143-160.

SzederkénYI, T. 2001: Tisza mega-unit. Prealpine evolution. - In: HAAS, J. (ed): Geology of Hungary, Eötvös University Press, Budapest, 148-161. https://doi.org/10.1007/978-3-642-21910-8

SUDAR, M. \& KovÁCS, S. 2006: Metamorphosed and ductilely deformed conodonts from Triassic limestones situated beneath ophiolite complexes: Kopanoik Mountain (Serbia) and Bükk Mountain (NE Hungary) a preliminary comparison. — Geologica Carpathica $\mathbf{5 7 / 3}, 157-176$.

Tari, G., Horváth, F. \& Rumpler, J. 1992: Styles of extension in the Pannonian Basin. — Tectonophysics 208, $203-219$. https://doi.org/10.1016/0040-1951(92)90345-7

WinTER, O. D. 2001: An introduction to igneous and metamorphic petrology. — Prentice Hall, Upper Saddle River, New Yersey, $697 \mathrm{p}$

YARDLEY, B. W. D. 1989: An introduction to metamorphic petrology. — Longman Scientific \& Technical, Essex, England, 248 p

ZÖLDFÖLDI, J. 2003: Provenance of the White Marble Building Stones in the Monuments of Ancient Troia. - In: WAGNER, G. A., Pernicka, E. \& Uerpmann, H. P. (eds): Troia and the Troad, Springer, Berlin, 203-222. https://doi.org/10.1007/978-3-662-05308-9

ZÖLDFÖLDI, J. 2011: 5000 Years Marble History in Troia and the Troad, Petroarchaeological Study on the Provenance of White Marbles in West Anatolia. — Doktori értekezés, Tübingen, 290 p.

Kézirat beérkezett: 2017. 03. 27. 


\section{I. tábla-Plate I}

A márványokban előforduló jellegzetes szilikátásványok, valamint a deformációs ikerlemezek morfológiai típusai; a minták a Dorozsma-54 és a Baksa-2 fúrásból származnak.

(A) Finomszemcsés, heteroblasztos szövetú, karbonát + kvarc összetételú márvány (Do-54; 27759).

(B) Heteroblasztos szövetû, tremolit tartalmú dolomárvány (Baksa-2; 840,1 m).

(C) Nagyon finomszemcsés kőzetváltozat karbonát + Mg-klorit összetétellel (Do-54; 27875).

(D) Finomszemcsés, diopszid és káliföldpát tartalmú márvány (Baksa-2; 137,5 m).

(E) Vékony vonalként jelentkező I. típusú ikerlemezek (Do-54; 27765).

(F) Vastag, táblás megjelenésú II. típusú ikerlemezek (Do-54; 27762).

(G) Szemcsehatár felé fokozatosan elvékonyodó, III. típusú deformációs ikerlemezek (Do-54; 27763).

(H) Foltszerú megjelenésú, IV. típusú ikerlemezek (Do-54; 27761).

Characteristic silicate minerals of marbles and the morphological types of deformation twins; samples from borehole Dorozsma-54 and Baksa-2:

(A) Fine-grained marble with heteroblastic texture composed of carbonate + quartz (Do-54; 27759).

(B) Tremolite-bearing dolomite marble with heteroblastic texture (Baksa-2; $840.1 \mathrm{~m}$ ).

(C) Very fine-grained rock type with a composition of carbonate $+M g$-chlorite (Do-54; 27875).

(D) Diopside and K-feldspar-bearing fine-grained marble (Baksa-2; $137.5 \mathrm{~m}$ ).

(E) Type I: the twins appear as thin black lines in the grains (Do-54; 27765).

(F) Type II: thick tabular twins with type I twins (Do-54; 27762).

(G) Type III: the twins are slightly tapered toward the grain boundary (Do-54; 27763).

(H) Type IV: thick patchy twins and the trails of tiny grains (Do-54; 27761). 


\section{I. tábla - Plate I}
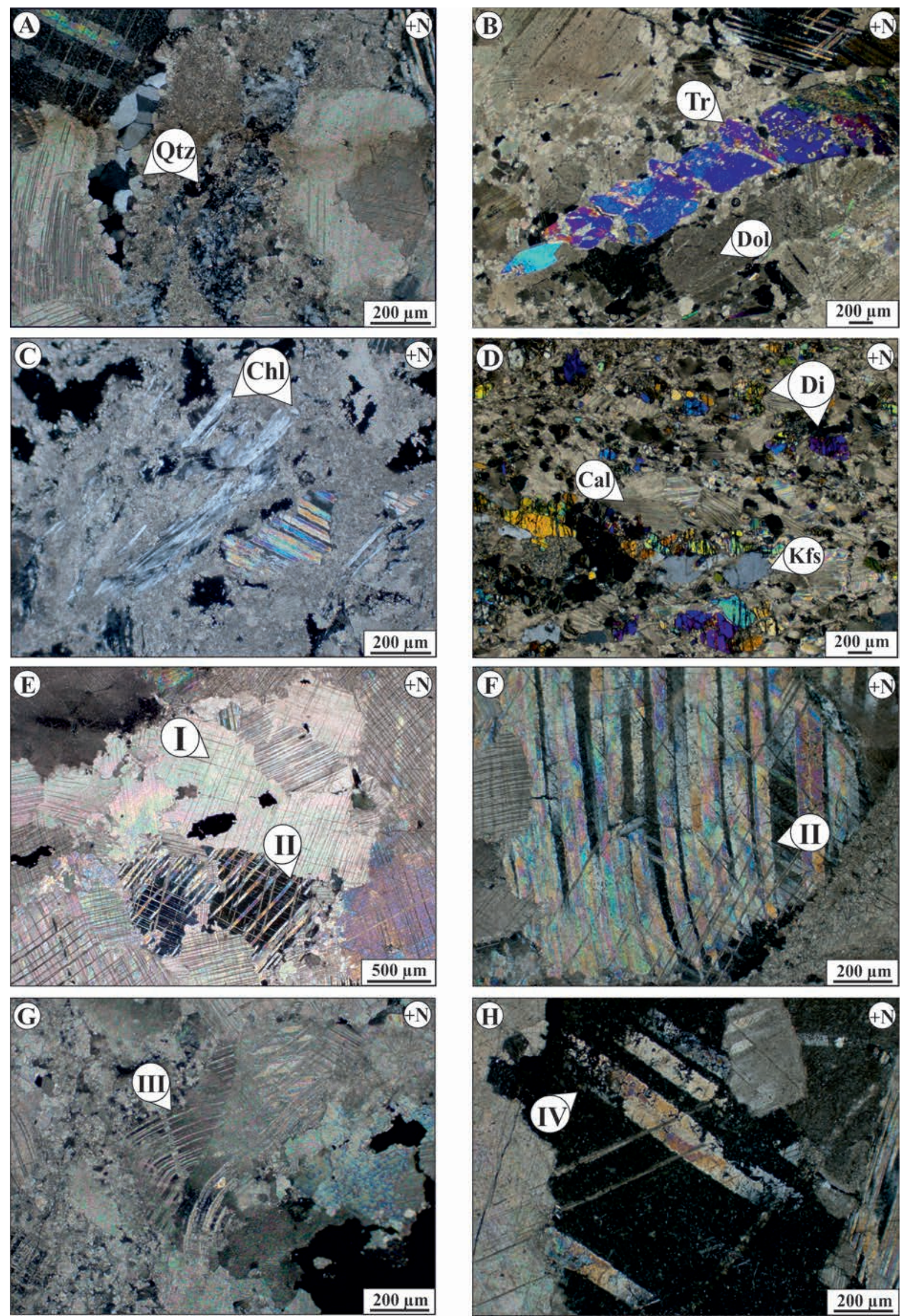


\section{II. tábla — Plate II}

A Dorozsma-54 fúrásban található márvány szöveti jellegzetességei.

(A) Egyensúlyi, homeoblasztos szövetú, nagyon finomszemcsés márvány, egyenes szemcsehatárokkal és $120^{\circ}$-os szemcseérintkezési szöggel (Do-54; 27326).

(B) Heteroblasztos szövetú, finomszemcsés márvány szutúrált szemcsehatárokkal (Do-54; 27759).

(C) I., II., és IV. típusú deformációs ikerlemezek karbonátszemcsében (Do-54; 27761).

(D) I. típusú és hajlott II. típusú deformációs ikerlemezek (Do-54; 27759).

(E) Mikrokristályos szegéllyel rendelkezó oldódásos üreg, amelyet tömbös kvarc tölt ki, az üreg peremén pedig apró karbonátszemcsék figyelhetők meg (Do-54; 27759).

(F) Idiomorf, zónás karbonátkristályok az oldódásos üreg falán (Do-54; 27878).

(G) Mikrokristályos kvarccal kitöltött ér finomszemcsés karbonátperemmel (Do-54; 27759).

(H) Fenn-nôtt kvarckristályok által kitöltött ér (Do-54; 27759).

Characteristic fabrics of the marble from the core Dorozsma-54:

(A) Homeoblastic texture of very fine-grained marble with crystals showing triple junction at $120^{\circ}$ and straight grain boundaries (Do54; 27326).

(B) Heteroblastic texture of fine-grained marble showing sutured grain boundaries (Do-54; 27759).

(C) Type I, II and type IV deformation twins in a single carbonate grain (Do-54; 27761).

(D) Type I and deformed type II twins (Do-54; 27759).

(E) Vuggy pore lined by tiny carbonate grains and filled by blocky quartz (Do-54; 27759).

(F) Idiomorphic carbonate grain showing zonation at the margin of the vug (Do-54; 27878).

$(G)$ Vein with very fine-grained carbonate margin and microcrystalline quartz infilling (Do-54; 27759).

(H) Vein filled with blocky quartz (Do-54; 27759). 
II. tábla — Plate II
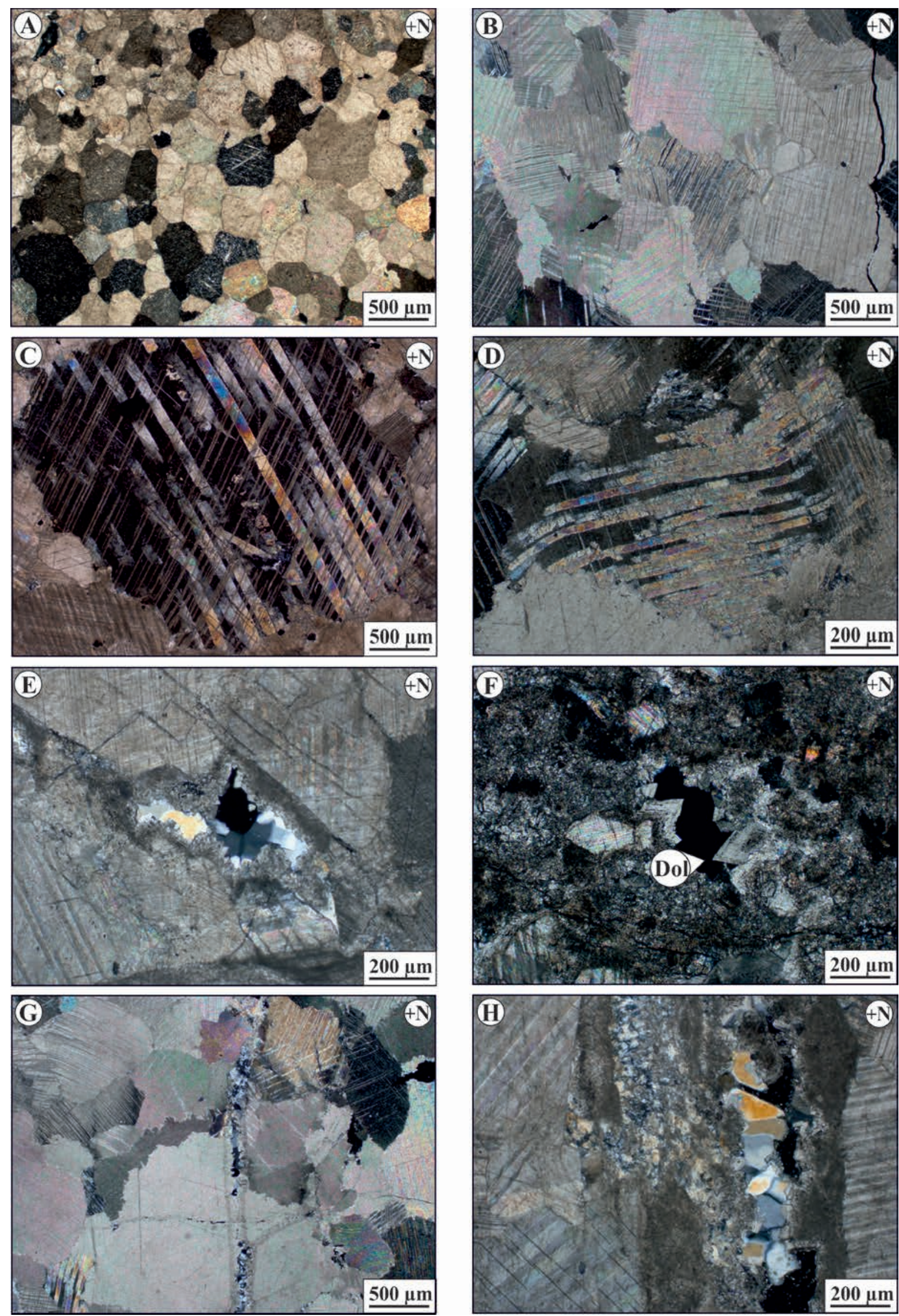


\section{III. tábla-Plate III}

A Dorozsma-54, a Dorozsma-4, valamint a Dorozsma-7 fúrásokból származó márványok szöveti jellegzetességei.

(A) Nagyon finomszemcsés kőzetváltozat, helyenként mikrokristályos kova helyettesítéssel (Do-54; 27763).

(B) Mikrokristályos (<5 ㅆm) kőzetváltozat a Dorozsma-4 fúrásból (Do-4; 14-1(2)).

(C) Deformációs sáv oldódási nyomokkal. A sávtól távolodva a szemcseméret növekedése figyelhető meg (Do-54; 27341).

(D) Korrodált karbonátszemcsék mikrokristályos karbonát és kova alkotta mátrixban, a rezorbeált szemcséken továbbnövekedési perem figyelhető meg (Do-54; 27341).

(E) Deformációs ikerlemezt helyettesítő apró, zárványmentes karbonát (dolomit) szemcsék (nyíl) (Do-4; 14-1(2)).

(F) Finomszemcsés, heteroblasztos szövetú márvány mag-köpeny szerkezettel (Do-4; 14-1 (2)).

(G) Nagy méretû, szigmoid alakú karbonátklasztok a mikrokristályos mátrixban (Do-7; 8-1-d(2)).

(H) Szabálytalan alakú, alszemcsés szerkezetú, unduláló kioltású polikristályos kvarcklasztok a nagyon finomszemcsés karbonát mátrixban (Do-7; 8-1-d(2)).

Characteristic fabrics of the marble samples from the cores Dorozsma-54, Dorozsma-7 and Dorozsma-4:

(A) Very fine-grained rock type with a microcrystalline quartz replacement (Do-54; 27763).

(B) Microcrystalline $(<5 \mu \mathrm{m})$ rock type in the core Dorozsma-4 (Do-4; 14-1(2)).

(C) Deformation band with traces of dissolution. The average grain size increases away from the deformed zone (Do-54; 27341).

(D) Corroded carbonate grains in a matrix composed of very fine-grained carbonate and microcrystalline quartz. At the rim of the carbonate grains overgrowth margin can be identified (Do-54; 27341).

(E) Deformation twins are replaced by tiny, inclusion free carbonate (dolomite) grains (arrow) (Do-4; 14-1(2)).

$(F)$ Fine-grained marble with heteroblastic texture showing core-mantle structure (Do-4; 14-1 (2)).

$(G)$ Carbonate grains showing sigmoid shape in the microcrystalline matrix (Do-7; 8-1-d(2)).

(H) Irregular shaped polycrystalline quartz grains with dissolved edges, undulose extinction and signs of dynamic recrystallization in the very fine-grained carbonate matrix (Do-7; 8-1-d(2)). 


\section{III. tábla — Plate III}
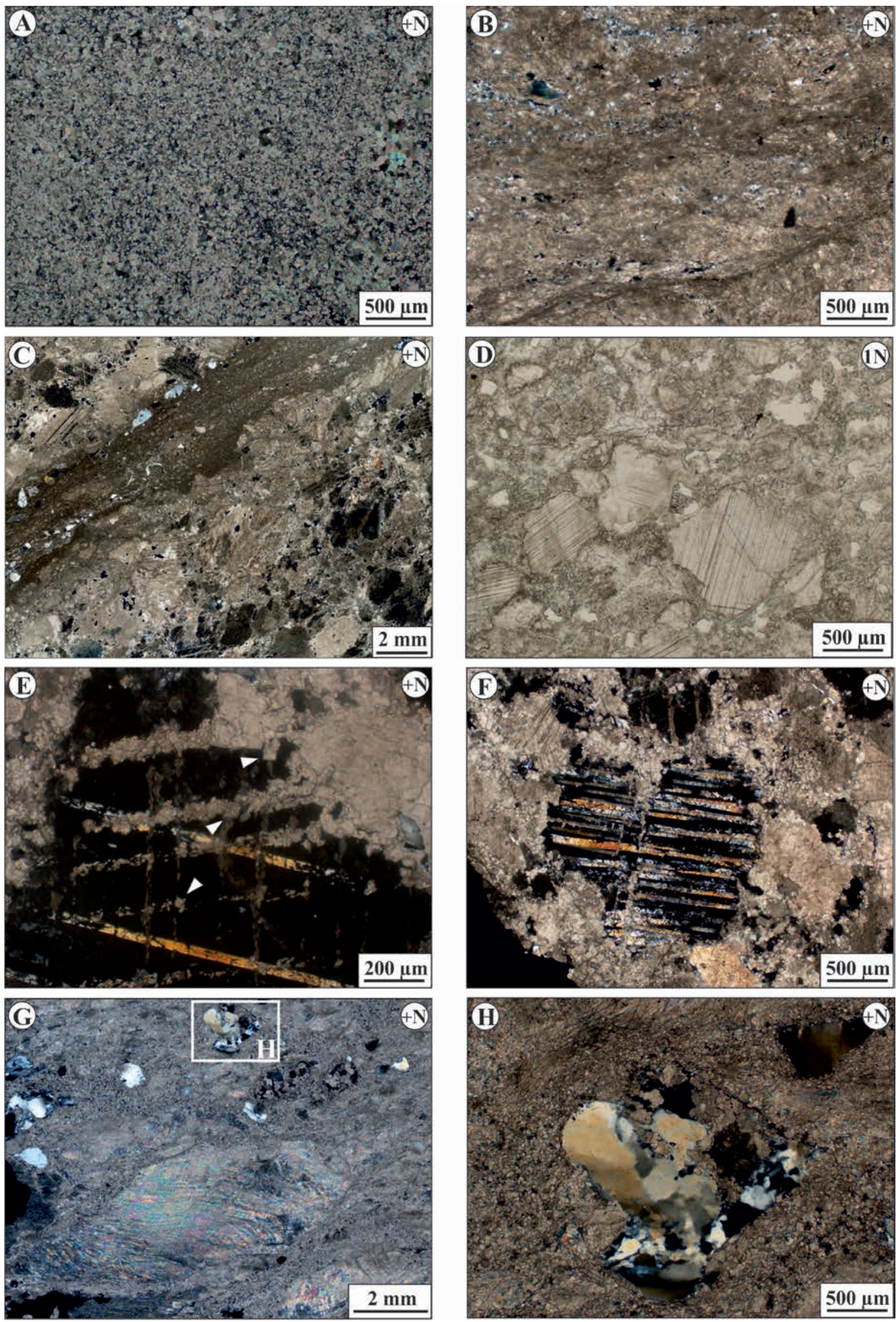
